University of Michigan Law School

University of Michigan Law School Scholarship Repository

Articles

Faculty Scholarship

1996

\title{
Tax Transitions, Opportunistic Retroactivity, and the Benefits of Government Precommitment
}

Kyle D. Logue

University of Michigan Law School, klogue@umich.edu

Available at: https://repository.law.umich.edu/articles/1743

Follow this and additional works at: https://repository.law.umich.edu/articles

Part of the Administrative Law Commons, Contracts Commons, Law and Economics Commons, Taxation-Federal Commons, and the Tax Law Commons

\section{Recommended Citation}

Logue, Kyle D. "Tax Transitions, Opportunistic Retroactivity, and the Benefits of Government Precommitment." Mich. L. Rev. 94, no. 5 (1996): 1129-96.

This Article is brought to you for free and open access by the Faculty Scholarship at University of Michigan Law School Scholarship Repository. It has been accepted for inclusion in Articles by an authorized administrator of University of Michigan Law School Scholarship Repository. For more information, please contact mlaw.repository@umich.edu. 


\title{
TAX TRANSITIONS, OPPORTUNISTIC RETROACTIVITY, AND THE BENEFITS OF GOVERNMENT PRECOMMITMENT
}

\author{
Kyle D. Logue*
}

"[T]he maximal exploitation of present possibilities may often be an obstacle to the maximal creation of new possibilities."1

"Discretion is the enemy of optimality, commitment its ally."2

\section{INTRODUCTION}

What if the current federal income tax laws were repealed and replaced with a simple flat tax? What if the entire Internal Revenue Code (with its graduated rates and countless deductions, exclusions, and credits) were scuttled in favor of a broad-based consumption tax? Only a few years ago, such proposals would have seemed radical and extremely unlikely to be adopted. But times are changing. Calls for a drastic overhaul of the Internal Revenue Code have become commonplace, even at the highest levels in the tax-policy community. ${ }^{3}$ In addition, proposals that would replace the income tax with a flat-rate broad-based consumption tax have received substantial bipartisan support in Congress. 4 And many

* Assistant Professor of Law, University of Michigan Law School. B.A. 1987, Auburn University; J.D. 1990, Yale University. - Ed.

I received helpful comments on earlier drafts of this article from Steve Croley, Heidi Feldman, Merritt Fox, Peter Hammer, Jon Hanson, Rick Hills, John Jackson, Avery Katz, Mark Killenbeck, Jim Krier, Jeff Lehman, Rick Lempert, Bill Miller, Rick Pildes, Bob Rasmussen, Stuart Thiel, and workshop participants at the University of Michigan, New York University, and Vanderbilt Law Schools. I received generous research support from the University of Michigan Law School Cook Research Fund. I also wish to thank Michael Graetz, Louis Kaplow, Jeff Stmad, and other participants at the Harvard Law School Seminar on Current Research in Taxation (Aug. 1994) for comments and suggestions on the initial draft of this article.

1. JON Elster, Ulysses and the SIRENS: StUdies in Rationality and IrRationalITY 10 (1984) (paraphrasing JOSEPH SCHUMPETER, A HISTORY OF ECONOMIC ANAL YSIS 87 (1954)).

2. Kenneth A. Shepsle, Discretion, Institutions, and the Problem of Government Commitment, in Social TheORY FOR A Changing Society 245-46 (Pierre Bourdieu \& James S. Coleman eds., 1991).

3. See, e.g., Robert E. Hall \& Alvin Rabushka, The Flat Tax 1 (2d ed. 1995) (quoting Shirley Peterson, former Commissioner of the Internal Revenue Service) ("I would repeal the entire Internal Revenue Code and start over.").

4. Representative Richard Armey, for example, has proposed a flat tax of $17 \%$ to be applied only to wages and pension income with an exclusion for investment income. Because of the exclusion for investment income, the Armey flat tax is a form of consumption tax. For 
commentators believe that Congress is likely to enact some version of these proposals in the not-too-distant future. ${ }^{5}$

One of the most important issues raised by the prospect of radical tax reform is that of transition effects. ${ }^{6}$ Each of the tax-reform proposals currently under consideration would eliminate many of the deductions, exclusions, and credits that individuals and businesses have come to rely upon. ${ }^{7}$ Therefore, unless Congress accompanies the repeal of those provisions with some form of transition relief (such as grandfathered, phased-in, or delayed effective dates) any taxpayer who made an investment in reliance on the prior rule will suffer substantial transition losses, losses in the value of pretransition investments.

As the tax-reform movement gathers momentum, however, so too will the pressure on lawmakers not to provide transition relief to those taxpayers who will be harmed by the reforms. This pressure comes from several sources. First, Congress may feel the need to keep tax reform at least revenue neutral, and transition relief may be the most obvious way of saving money. 8 Second, politicians may see tax reform as an opportunity actually to raise revenue. Given the political risk associated with being the congressperson

the classic description of a consumption-based flat tax upon which the Armey plan is based, see HalI \& RUBUSHKA, supra note 3. Another recent proposal for replacing the current income tax with a broad-based consumption tax that has received a great deal of attention is the plan put forward by Senators Sam Nunn and Pete Domenici, called the Unlimited Savings Allowance (USA) Tax System. See H.R. 2060, 104th Cong., 1st Sess. § 101 (1995); S. 722, 104th Cong., 1st Sess. (1995) (dubbing the proposal the "USA Tax Act of 1995"). Under the USA tax system, taxpayers essentially would be allowed to deduct amounts set aside for savings or investment; thus, the USA tax amounts to a cash-flow consumption tax as well. For a general discussion of these and other recent flat-tax-reform proposals, see JoINT Comm. ON TAXation, 104th Cong., 1st Sess., Discussion of Issues Relating to FLAT TAx Rate Proposals (Comm. Print 1995).

5. See, e.g., Jerry Heaster, Reform, Via a Flat Tax, Seems Likely, KAN. CrTY STAR, May 7, 1995, at G1 (quoting economists and political analysts who view radical tax reform as highly likely in coming years); Sheldon D. Pollack, Consumption Taxes, Flat Taxes, Capital Gains, and Other Tax Fantasies, 66 TAX Notes 577, 578 (1995) ("[T]here is surprisingly strong support on both sides of the aisle in Congress for both of these very radical tax proposals [cut in the capital gains tax and replacement of the federal income tax], and hence, they must be considered as viable political options."); David E. Rosenbaum, Washington Memo: Debate of Flat Tax Revives Simplicity vs. Fairness Issue, N.Y. Times, April 18, 1995, at A1.

6. See, e.g., JoINT COMM. ON TAXATION, supra note 4, at 27-28.

7. For example, the Hall-Rabushka flat tax would eliminate all deductions other than the deduction for the costs of inputs used in the production of goods and services, including the costs of plant and equipment and employee wages and salaries; it also would eliminate all credits and exclusions, other than the personal exemption. See Hall \& Rabushka, supra note 3, at 110-11. Note, however, that the flat tax, despite its name, would retain a degree of progressivity because of the personal exemption.

8. See, e.g., Alliance USA, Description and Explanation of the Unlimited Savings Allowance Income Tax System, 66 TAx Notes 1481, 1487 (1995) ("The USA Tax System is designed to replace on a revenue-neutral basis the present corporate and individual income taxes ...."). 
who votes for a tax-rate increase, lawmakers may find the prospect of foregoing transition relief an atractive alternative source of revenue. Finally, lawmakers may be concerned about the perceptions of unfairness sometimes associated with the enactment of transition rules designed to protect particular taxpayers or groups of taxpayers.

In addition to the political forces pushing against the provision of transition relief in tax reform, the dominant view in the legal academy also opposes government-provided protection for losses arising from changes in the tax laws. Professor Michael Graetz, in a 1977 article, ${ }^{9}$ and Professor Louis Kaplow, in a 1986 article, ${ }^{10}$ present an elegant and compelling argument that Congress should adopt a policy of providing little or no transition relief to taxpayers who suffer losses owing to unanticipated tax-law changes. Put differently, under the Graetz-Kaplow theory, tax-law changes (indeed, all legal changes) should be made fully retroactive. ${ }^{11}$ That argument has gone largely unchallenged in the legal academy. ${ }^{12}$ Moreover, Professor Saul Levmore, taking the case for retroactive taxation one step further, has argued that the occasional, unexpected use of retroactive taxation may provide a potentially rich and nondistortionary source of revenue for the government. ${ }^{13}$

This article challenges the conventional academic wisdom that nominal retroactivity is presumptively efficient. In contrast to the Graetz-Kaplow view, I argue that, for certain types of tax transitions, the efficient transition policy entails full transition relief in the form of guaranteed grandfathering. The article is arranged as follows: Part I describes the issue of tax transitions more generally and details the Graetz-Kaplow efficiency argument for denying compensation to taxpayers who suffer tax-transition losses. Part II then defines a category of tax transitions for which the optimal

9. Michael J. Graetz, Legal Transitions: The Case of Retroactivity in Income Tax Revision, 126 U. PA. L. REv. 47, 87 (1977) [hereinafter Graetz, Retroactivity].

10. Louis Kaplow, An Economic Analysis of Legal Transitions, 99 HARv. L. REv. 509 (1986).

11. Graetz and Kaplow's positions with respect to tax transitions are discussed in more detail infra in Parts I and III.

12. There have been two noteworthy articles rejecting the Graetz-Kaplow conclusion, at least with respect to some types of tax transitions. See Daniel S. Goldberg, Tax Subsidies: One-Time v. Periodic An Economic Analysis of the Tax Policy Alternatives, 49 TAx L. Rev. 305 (1994); J. Mark Ramseyer \& Minoru Nakazato, Tax Transitions and the Protection Racket: A Reply to Professors Graetz and Kaplow, 75 VA. L. Rev. 1155 (1989). I discuss the Goldberg article infra in section V.B.4 and the Ramseyer-Nakazato article infra in section III.D.

13. See Saul Levmore, The Case for Retroactive Taxation, 22 J. Legal Stud. 265, 273-78 (1993). I discuss Levmore's arguments infra in section IV.B.2. 
transition policy probably is full transition relief in the form of grandfathered effective dates. ${ }^{14}$ That category is composed of changes in incentive subsidies, that is, tax provisions designed by Congress to alter taxpayers' incentives or, more specifically, to induce taxpayers to increase their investment in some socially desirable activity. To make the case for guaranteed grandfathering, I exploit the analogy between incentive subsidies and government contracts. My argument is essentially this: We generally believe it is a good idea for the government to keep its contractual promises, those made to private parties and those made to other governments. Indeed, I argue that in most situations involving implicit or explicit government contracts our policy is that the government must keep its word. Next, I argue that, for the same reasons we follow such a policy in cases of government contracts, we should follow such a policy with respect to incentive-subsidy provisions, which are analogous to contracts in important ways. As I explain below, such a transition policy requires the government to guarantee grandfather treatment whenever an incentive subsidy is repealed or substantially reduced. Failure to make such a commitment can produce a number of problems, including an inefficient increase in the default premium that the government must pay taxpayers to compensate them for the risk of tax transitions. Failing to provide transition relief in such contexts, I argue, amounts to opportunistic behavior on the part of the government.

Part III responds to a number of specific objections that might be raised in response to my argument. Part IV then begins to draw a distinction between incentive-subsidy transitions and other types of tax transitions for which efficiency may require some degree of retroactivity. This latter class of tax transitions includes legislative corrections of obvious drafting errors and broad-based tax transitions such as an increase in tax rates or a shift from an incomebased to a consumption-based tax. Therefore, Part IV agrees with Levmore that some nominally retroactive tax changes can have effciency benefits, but it suggests that those benefits are easily overstated. Finally, Part V concludes with a discussion of some of the practical problems associated with designing an efficient grandfathering policy, and it provides a brief examination of some ways in which the government could precommit to the transition policy described in Part II.

14. Although I sometimes use the language of "efficiency," the normative criterion that I apply, as do Graetz, Kaplow, and others, is a version of utilitarianism. See infra note 40. 


\section{Tax Transitions: The Debatë}

\section{A. Defining Transition Losses and Transition Relief}

Any time Congress changes the federal income tax laws and any time the Treasury Department or a court alters its interpretation of those laws, there typically will be a class of taxpayers who will suffer transition losses. Likewise, tax-law changes also give rise to transition gains; those taxpayers who are holding investments that happen to benefit from a tax change suddenly experience a windfall increase in the value of those investments. ${ }^{15}$

The classic illustration of these concepts involves the repeal of the exemption for interest on state and local bonds. Suppose a taxpayer were to purchase a long-term bond that paid interest in annual installments with the principal returned at the date of maturity. Assuming for simplicity that this investment is risk-free, the price of the bond would be equal to the discounted present value of the after-tax cash flow that the taxpayer expects to receive on the bond. Assume that, at the time of purchase, the interest on the bond is exempt from federal income taxation and therefore the price of the bond would equal the discounted value of the pretax cash flow. Now suppose that, in the following year, Congress repeals the interest exemption and provides no ransition relief to taxpayers who made investments in reliance on the old exemption. The value of the taxpayer's formerly exempt bond would fall, and the taxpayer would suffer a transition loss. Likewise, when the tax exemption was first enacted, the lucky or clever taxpayers who happened to have purchased their bonds prior to the passage of the exemption would enjoy transition gains.

Transition losses can occur whether the new tax law or new interpretation applies nominally retroactively or nominally prospectively. ${ }^{16}$ Under a nominally retroactive tax-law change, the change applies not only to income that is earned after the date of enactment but also to income eamed before the date of enactment. ${ }^{17}$ Under a nominally prospective income tax change, however, the new law applies only to income earned after the date of enactment

15. See Kaplow, supra note 10, at 517; Michael J. McIntyre, Transition Rules: Learning to Live With Tax Reform, 4 TAX NOTES 7, 12 (1976).

16. See Graetz, Retroactivity, supra note 9, at 57-60.

17. For examples of nominally retroactive tax transitions, see infra section IV.A (discussing the Carlton case) and IV.B.2 (discussing retroactive income tax rate increases). Most nominally retroactive tax changes apply only to the year in which the change is enacted. Theoretically, a retroactive tax change also could apply to income eamed in tax years prior to the year of enactment. If the tax change applies to earlier years, however, it might indeed run afoul of the Constitution. See infra note 130 (citing sources). 
and, often, only to income earned after the end of the year of enactment. Under either type of transition, if the change applies to income earned on pre-enactment investments and is not anticipated by taxpayers, transition losses will occur. ${ }^{18}$ Returning to the taxexempt-bond example, as long as the repeal of the tax exemption applies to future income on bonds that were purchased before the repeal was enacted, there will be transition losses. ${ }^{19}$

When enacting changes in the federal tax laws, Congress often provides some type of transition relief. For example, Congress frequently uses nominally prospective effective dates for new tax laws. In some circumstances, however, Congress instead uses phased-in, delayed, or grandfathered effective dates. Under a phased-in effective date, the change is made effective gradually, and the transition effects are mitigated (spread over time) but not eliminated. Under a delayed effective date, the change is announced upon enactment but made effective at some later date. This, too, provides only partial transition relief. Under a grandfathered effective date, however, the new tax provision applies only to income earned on investments that are made after the date on which the change is enacted or after some later date. ${ }^{20}$ Thus, grandfathered effective dates essentially provide full transition relief or full protection against tax-transition losses. As discussed in section II.C below, however, there are circumstances in which a grandfathered effective date provides less-than-full relief or more-than-full relief, depending on whether the grandfather treatment is made transferable.

Congress is not the only source of tax-transition losses. When the Treasury Department issues new regulations or rulings or when a court renders a decision interpreting the tax laws, similar losses can occur. In the case of rulings and regulations, the Treasury Department is authorized by statute to provide transition relief in the form of nominally prospective effective dates. ${ }^{21}$ Absent Treas-

18. Professor Graetz was the first to draw the distinction between effective dates that are nominally prospective and those that are nominally retroactive. More important, he was the first to demonstrate that applying a transition nominally prospectively will not provide full transition relief. See Graetz, Retroactivity, supra note 9. Note, however, that, with respect to certain types of incentive-subsidy provisions, such as an "up-front" incentive subsidy, a nominally prospective effective date will provide almost full transition protection against the risk of a repeal. See infra section.V.B.5 (discussing up-front incentive subsidies).

19. See Graetz, Retroactivity, supra note 9, at 57-60.

20. See David F. Bradford \& U.S. TReasury Tax Policy StafF, Blueprints for BASIC TAX REFORM 166-68 (2d ed. 1984) [hereinafter BLUEPRINTs]; Graetz, supra note 9, at 60.

21. Code $\S 7805$ (b) empowers the Treasury Department to decide whether to apply regulations retroactively: "The Secretary may prescribe the extent, if any, to which any ruling or 
ury Department action, however, the new regulations and rulings are automatically applied nominally retroactively. ${ }^{22}$

In contrast to the Treasury Department's practice, courts rarely provide transition relief. When a court issues a decision interpreting a tax provision for the first time, the court almost always applies its new interpretation retroactively; that is, it applies the interpretation to the taxpayer in the case before it and typically to all taxpayers who present similar situations, even if their conduct took place before the decision. This practice is consistent with courts' longstanding tradition of applying most judicial decisions retroactively. ${ }^{23}$

Transition losses and gains, of course, are not limited to changes in tax laws. They can be observed in connection with any type of legal transition: for example, an increase in airline-safety standards or a decrease in federal defense spending. ${ }^{24}$ Although this article focuses on the issue of tax transition losses, much of the analysis applies to other legal transitions as well.

\section{B. Should the Government Compensate Transition Losses?}

The critical normative question raised by tax transitions is whether the government should provide transition relief. ${ }^{25}$ For

regulation, relating to the internal revenue laws, shall be applied without retroactive effect." I.R.C. \& 7805(b) (1996).

22. The Treasury Department's discretion under $\$ 7805(\mathrm{~b})$ has limits. For example, if a regulation has existed unchanged for many years, it may acquire the force of law, in which case retroactive repeal can come only from Congress. See Helvering v. R.J. Reynolds Tobacco Co., 306 U.S. 110 (1939). See generally BORIS I. BMTKER \& LAWRENCE LOKKen, FEDERAL TAXATION OF INCOME, EsTATE, AND GIFTS II 110.4.3 (1992).

23. See Kuhn v. Fairmont Coal Co., 215 U.S. 349, 372 (1910) (Holmes, J., dissenting) ("Judicial decisions have had retrospective operation for near a thousand years."). See generally Harper v. Virginia Dept. of Taxation, 113 S. Ct. 2510 (1993) (surveying the Supreme Court's jurisprudence on retroactive application of constitutional decisions). The primary exception to the rule of retroactive application of judicial decisions comes in the civil context, where a "new principle of law" can be applied prospectively, if prospective application would avoid "injustice and hardship" without unduly undermining the "purpose and effect" of the new rule. See Chevron Oil Co. v. Huson, 404 U.S. 97, 106-07 (1971).

24. See Kaplow, supra note 10, at 515-19.

25. A similar question often has been addressed in connection with nontax legal transitions. For example, much of the literature on the Takings Clause of the U.S. Constitution includes analyses of the question whether the government should provide compensation to citizens whose property it takes for a public purpose. E.g., Lawrence Blume \& Daniel L. Rubinfeld, Compensation for Takings: An Economic Analysis, 72 CAL. L. REv. 569 (1984); Lawrence Blume et al., The Taking of Land: When Should Compensation be Paid? 99 Q.J. ECoN. 71 (1984); Louis De Alessi, Implications of Property Rights for Government Investment Choices, 59 AM. Econ. Rev. 13 (1969); William A. Fischel \& Perry Shapiro, Takings, Insurance, and Michelman: Comments on Economic Interpretations of "Just Compensation" Law, 17 J. Legal Stud. 269 (1988); Kaplow, supra note 10; Frank Michelman, Property, Utility and Fairness: Comments on the Ethical Foundations of "Just Compensation" Law, 80 HARV. L. Rev. 1165 (1967). 
many years, the dominant view was that tax changes should not be applied retroactively. ${ }^{26}$ This view apparently derived from the belief that retroactive application would upset taxpayers' "reasonable expectations" regarding the tax treatment of investments they had made "in reliance" on the prior law. ${ }^{27}$ This view of tax transitions is sometimes referred to as "old view."28 As stated, however, such a reliance-based defense of transition relief begs the relevant question: Do taxpayers in such situations have a normative claim to a government-provided guaranty of the tax treatment of pretransition investments?

Two of the most comprehensive attempts to answer this question came in the scholarship of Professors Graetz and Kaplow. ${ }^{29}$ Although their analyses are distinguishable in important ways, ${ }^{30}$ their arguments can be usefully combined and summarized as follows:

(1) In the U.S. economy, investors constantly face risks of one kind or another (for example, the risk of unanticipated inflation or a shift in consumer preferences) which can be called "market risks." Moreover, with a few exceptions, the government typically does not provide insurance for such risks. To the contrary, efficient market incentives are best maintained if investors bear the full costs of their investments.

26. See Michael J. Graetz, Implementing a Progressive Consumption Tax, 92 HARv. L. REv. 1575, 1650 (1979) [hereinafter Graetz, Consumption Tax] ("The politically dominant approach to significant changes in the tax law has been to protect the expectations of taxpayers who have 'relied' on existing law; protection typically takes the form of 'grandfathered' effective dates.") (citing, among other sources, BLUEPRINTs, supra note 20, at 181-215; and INSTIIUTE FOR FISCAL STUDIES, THE STRUCTURE AND REFORM OF DIRECT TAXATION 18792, 198-200 (1978)).

27. E.g., Committee on Tax Policy, New York State Bar Association, Retroactivity of Tax Legislation, 29 TAX Law. 21 (1975); Note, Setting Effective Dates for Tax Legislation: A Rule of Prospectivity, 84 HARv. L. REv. 436 (1970).

28. See Levmore, supra note 13 , at 267-68.

29. Other particularly cogent and infiuential analyses of tax transitions include BLUEPRINTS, supra note 20, at 159-87; and McIntyre, supra note 15.

30. Kaplow concludes that, under certain assumptions, all forms of tax-transition relief are generally undesirable. See Kaplow, supra note 10, at 615 . Graetz, however, would permit the occasional use of phased-in or delayed effective dates, depending upon the magnitude of the wealth loss the transition causes. See Graetz, Retroactivity, supra note 9, at 87. Another distinctive part of Kaplow's treatment of legal transitions is its comprehensiveness. Not only does he address transition losses that result from any type of legal transition (not just tax transitions), but he also addresses the symmetrical issue of transition gains (or "windfall gains") that result when taxpayers see the value of the pretransition investment rise as a result of the legal transition. Kaplow correctly notes that all the same issues apply to windfall gains. See Kaplow, supra note 10, at 553-55. 
(2) The risk that the government may change the tax laws in a manner that reduces the value of taxpayers' pretransition investments is not significantly different from market risk.

(3) Therefore, the efficiency criterion generally supports a transition policy under which the government does not compensate transition losses but instead leaves private investors to bear the risk of tax-law changes. ${ }^{31}$

Kaplow generalizes this government-risk argument to all forms of legal transitions:

Generally, transitional relief is inefficient because it insulates investors from the real effects of their decisions, and thus distorts their behavior.... Given the close kinship between uncertainty regarding government policy and market uncertainty, the belief that market responses are typically more efficient than government relief in addressing market risk suggests that transitional relief in mitigation of uncertain government policy is likewise undesirable. ${ }^{32}$

$\mathrm{He}$ also stated that "[the] simultaneous consideration of risk and incentives leads to the conclusion that government transitional relief generally is undesirable. . . . [G]overnment compensation or other transitional relief usually is inefficient."33 Graetz makes the government-risk argument in the federal income tax context:

Recent tax legislation has tended to institutionalize expectations of grandfathered effective dates in the tax context. This should be reversed. The tax law must remain a flexible instrument of public policy. When a provision has outlived its usefulness, it should be eliminated without the delay and windfall gains inherent in grandfathering prior transactions. People should make investments with the expectation that political policies may change. ${ }^{34}$

The Graetz-Kaplow analysis therefore concludes that it would be inefficient for Congress to bind itself to apply a given tax rule to a given pretransition investment. Put differently, they conclude that it would be inefficient for Congress to commit to a policy of providing tax-transition relief in the form of grandfathered effective dates. ${ }^{35}$ Graetz ultimately concludes that, when transition losses are

31. See generally Graetz, Retroactivity, supra note 9, at 65-66, 87; Kaplow, supra note 10 , at $513-14,520,527-36$.

32. Kaplow, supra note 10 , at 513-14.

33. Id. at 615-16.

34. Graetz, Retroactivity, supra note 9, at 87. In fairness, Graetz and Kaplow both acknowledge a number of possible exceptions to their general arguments against transition relief. See Graetz, Retroactivity, supra note 9, at 87; Kaplow, supra note 10, at 616 \& n.336.

35. It is also worth noting that other scholars have come to view the Graetz-Kaplow analysis as standing for the rejection of grandfathered effective dates in tax transitions. See, e.g., Ramseyer \& Nakazato, supra note 12, at 1155 ("[Graetz and Kaplow] argue that Congress should abandon [the use of grandfather clauses] as economically inefficient and ethically superfluous."). 
expected to be extremely large, transition relief in the form of phased-in or delayed effective dates may be appropriate on effciency and fairness grounds, but grandfathered effective dates should not be used. ${ }^{36}$ Kaplow concludes generally that tax transitions should be fully, nominally retroactive. ${ }^{37}$ The Graetz-Kaplow view of tax transitions, sometimes referred to as the "new view,"38 has largely supplanted the old reliance-based view as the dominant scholarly paradigm. ${ }^{39}$

\section{InCENTIVe SubSidies AND the CASe for GuARANTEed GRANDFATHERING}

\section{A. The Default-Premium Effect and the Benefits of Government Precommitment}

This section discusses a category of tax transitions that, on efficiency grounds, should be accompanied by full transition relief in the form of grandfathered effective dates. ${ }^{40}$ Included in this category are repeals of or significant reductions in incentive subsidies, which I define as follows: provisions whose primary purpose is to alter taxpayers' decisions regarding how they will invest their resources. A simple example of such a provision is an incentive tax credit, of which there are many in the Internal Revenue Code. ${ }^{41}$ Congress frequently uses such credits to increase taxpayer investment in various types of targeted assets or activities, and such credits usually take the following form: If the taxpayer will increase her investment in the targeted asset or activity, some percentage of that increased investment will be allowed as a credit against the tax-

36. See Graetz, Retroactivity, supra note 9, at 87; Graetz, Consumption Tax, supra note 26, at 1650 ("[N]either faimess nor efficiency demands grandfathered effective dates, but ... when the magnitude of change is large, its impact should be reduced through delayed or phased-in effective dates rather than grandfathering."); id. at 1653 ("[G]randfathered effective dates should not be enacted to protect assets that have received favored treatment under the income tax.").

37. See Kaplow, supra note 10, at 551-52.

38. See Levmore, supra note 13 , at 268.

39. See id, Ramseyer \& Nakazato, supra note 12, at 1155-56. It is worth noting that, following Graetz's 1977 article, the Tax Section of the ABA issued a report adopting some of Graetz's recommendations. Special Comm. on Simplification, ABA Section of Taxation, Evaluation of the Proposed Model Comprehensive Income Tax, 32 TAX LAw. 563, 680-86 (1979).

40. The normative criterion applied through most of the article is a loose version of the Kaldor-Hicks variety, in other words, maximizing the size of the pie. Thus, typically when I say "efficient" or "optimal," I mean Kaldor-Hicks efficiency or optimality. At points in the article, however, I also address distributional concerns and how they may conflict with efficiency concems.

41. See infra notes 70-78. 
payer's federal income tax liability. As a result, an investment that would not have been profitable to the taxpayer absent the credit (that is, it would not have produced a positive net present value) becomes profitable once the credit is included.

An incentive tax credit can be designed in two general ways. First, it can be designed as an up-front credit, which means that the full amount of the credit applies to the taxpayer's tax liability in the year in which the investment giving rise to the credit is made. $.^{42} \mathrm{Sec}-$ ond, it can be designed as installment credit, which means that the credit generated by an investment made in one year is spread over a number of tax years. ${ }^{43}$ Note that the selection of the up-front or installment design will in turn affect the design of the appropriate transition relief. If an installment credit were repealed, for example, full transition relief would require a grandfather clause that exempts any investments made before the repeal was enacted or before some date prior to the repeal. If, however, an up-front credit is repealed, full transition relief simply means applying the repeal nominally prospectively, as the taxpayers who relied upon the credit already would have received the full tax benefit upon which they relied. In other words, an up-front credit has a built-in grandfather clause, assuming any repeal is nominally prospective. ${ }^{44}$

If Congress were to repeal an incentive tax credit without providing transition relief (either in the form of a grandfathered effective date for an installment credit or in the form of a nominally prospective effective date for an up-front credit) taxpayers who invested in reliance on the credit would suffer a transition loss. That possibility gives rise to the main point of this section: Because taxpayers who relied on the repealed incentive credit were "burned" by the government, future incentive credits would have to be more generous (for example, the credit percentage would have to be greater) to achieve the same amount of increased investment in the targeted asset or activity. This increase in the cost of the incentive credit can be understood as a default premium, the premium taxpayers demand to compensate them for the possibility that the government will repeal the incentive subsidy (in this example, the incentive credit) without providing transition relief.

42. See Kaplow, supra note 10, at 587 (coining the term "up front" subsidy).

43. Goldberg explores the distinction between up-front subsidies and installment subsidies in considerable detail. Although he uses different terminology ("one-time" subsidy and "periodic" subsidy, respectively) the concepts are the same as those discussed by Kaplow and by me. Goldberg, supra note 12.

44. See id. at 314; Kaplow, supra note 10, at 587. 
The size of the default premium will be a function of the taxpayers' subjective estimate of the probability that the government will repeal the credit without providing relief. To be specific, assuming risk-neutral taxpayers, the value of the default premium will be equal to $1 / 1-P_{\mathrm{t}}$, where $P_{\mathrm{t}}$ is the taxpayers' estimate of $P$, the probability of uncompensated repeal. The size of the premium would be greater if taxpayers were risk-averse with respect to the possibility of uncompensated repeal. Note that this defaultpremium observation would apply not only to the repeal of an incentive tax credit but also to the substantial reduction of such a credit. More significantly, the default-premium observation applies not only to incentive tax credits but also to the repeal of or reduction in any incentive subsidy.

I refer to this cost of the government's failure to provide transition relief has the default-premium effect. To reduce this cost, the government must make a credible public precommitment to provide transition relief. In Part V below, I discuss several possible precommitment devices that might be used in connection with incentive subsidies. ${ }^{45}$ Of course, although government precommitment to transition relief in this context may reduce the default-premium effect, such precommitment too comes at a cost. More specifically, it limits the government's ability to repeal incentive-subsidy provisions without having to provide transition relief. ${ }^{46}$ That cost of government precommitment (measured in terms of lost policymaking flexibility) could theoretically overwhelm the default-premium effect, in which case, guaranteed grandfathering would be inefficient.

There are reasons to believe, however, that the reverse is more likely to be true (that is, the default-premium effect is likely to dominate in this setting): Because the government actually has control over the probability of uncompensated repeal (in the absence of a binding commitment to provide transition relief) taxpayers in such a situation would have a tendency to assign a large value to $P_{\mathrm{t}}$. Thus, even if taxpayers were risk-neutral, they would have a tendency to demand a higher default premium than otherwise, that is, higher than if the government had no control over $P$. If taxpay-

45. Interestingly, Professor Kaplow concludes generally that the govemment should not commit to any substantive tax rule. He also concludes, however, that the govemment should commit itself to maintain an optimal transition policy, which he distinguishes from substantive tax rules. Therefore, Kaplow recognizes that there are efficiency benefits to the government's precommitment to transition policy; however, he concludes that the efficient transition policy is for the govermment not to provide transition relief. See Kaplow, supra note 10 , at $557-60$.

46. See infra section III.B (discussing the distinction between opportunistic and nonopportunistic legal transitions). 
ers were risk-averse, the size of the default premium would be even greater. This tendency for taxpayers to assign a relatively high value to the likelihood of uncompensated repeal strengthens the case for guaranteed grandfathering of incentive-subsidy provisions. ${ }^{47}$

Professor Graetz asserts that, if taxpayers' estimate of $P$ is equal to or less than the government's assessment of $P$ (in other words $P_{\mathrm{t}}$ $<$ or $=P_{\mathrm{g}}$ ), the payment of the default premium (as opposed to guaranteed transition relief) would unambiguously be the efficient result. ${ }^{48}$ That conclusion, however, either ignores the possibility that the government's precommitment costs could still be less than $P_{\mathrm{t}}$ or assumes that the government's precommitment costs are greater than $P_{\mathrm{t}}$. Either way, the conclusion needs further justification. In addition, Graetz completely ignores the fact that the government's control over $P$ will cause taxpayers to increase their subjective estimate of $P$.

In addition to the default-premium effect, if the government were to make a practice of actively inducing taxpayers to rely on

47. Graetz acknowledges the potential efficiency benefits of reducing the default premium (which he calls an "uncertainty premium") that would flow from the govemment's precommitment to the transition policy I have described. See Graetz, Retroactivity, supra note 9, at 69-70. He concludes, however, that a commitment by the government to provide grandfather treatment would be inefficient; further, he concludes that transition relief should be supplied only on an ad hoc basis, depending upon the magnitude of the transition loss in question. See id. at 87 . Kaplow, on the other hand, argues that it is always cheaper for the government to pay the default premium than to commit to grandfathering an incentivesubsidy repeal. See Kaplow, supra note 10, at 528-29. This argument seems clearly wrong, for the reasons discussed in the text.

Goldberg acknowledges the default-premium effect, and, like me, he regards it as a reason for providing transition relief in this context. See Goldberg, supra note 12 , at 327 . $\mathrm{He}$ does not explain why it would be efficient to have the government rather than the individual taxpayers bear the default premium. Indeed, Golberg's argument seems to be based primarily on an unspecified conception of fairness or horizontal equity. See id. at 323 ("If the subsidy is removed, however, transition rules should be enacted to prevent inequities ...."). In addition, Goldberg does not address the issue of government precommitment, and thus he does not suggest proposals for facilitating govemment precommitment to an optimal transition policy. Finally, Goldberg ignores the boundary between incentive subsidies and other types of tax provisions and the desirability of transition relief with respect to transitions in the latter type of provision.

Graetz also provides a Rawlsian analysis of what would constitute a "fair" transition policy from the perspective of the "original position;" he concludes that, "[i]n the context of a progressive income tax, the repeal of tax-favored treatment for particular investments would be the least likely category of change for which the parties would agree to require grandfather clauses." Graetz, Retroactivity, supra note 9, at 85 (quoting JOHN RAWLS, A THEORY OF JUSTICE 199 (1971)). His argument is that the parties most likely to benefit from a rule requiring grandfathering of such provisions are likely to be the "most-advantaged persons" in society rather than the least. See id. at 86 . But this conclusion does not follow. Which class of individuals will benefit most from such a transition policy depends upon how the government spends the money it saves in reduced default premiums resulting from the policy. That money could be distributed to the least-advantaged individuals in society, for example.

48. See Graetz, Retroactivity, supra note 9, at 70. 
incentive subsidies only to repeal those provisions retroactively, there would be additional costs. Tricking taxpayers in that way, even if such an approach were efficient in a narrow sense, in a broader sense, might be inefficient; for example, it might engender distrust and antipathy toward the government. ${ }^{49}$ That reaction in turn could undermine individuals' willingness to comply with the tax laws, an ominous prospect in the federal income tax context, as the system's success depends heavily upon a large degree of voluntary compliance or self-assessment on the part of taxpayers. ${ }^{50}$

Given the costs associated with the uncompensated repeal of or reduction in an incentive subsidy, an argument can be made that the government should attempt to precommit to a policy of providing guaranteed grandfather treatment for all incentive-subsidy provisions. That is, the government should institute devices or procedures designed to hinder violation of this optimal transition policy. Below I discuss the considerations that go into designing the appropriate grandfather rule and the appropriate precommitment device.51 But first, let us consider an important preliminary question: Why bother with government precommitment? Why not simply count on the govermment to make the correct tradeoff in each case between the benefits and costs of transition relief? Truth be told, lawmakers already may make this tradeoff optimally, at least some of the time. That possibility is discussed further in Part V.

There may be reasons, however, to doubt the ability of lawmakers to maintain an optimal transition policy over time purely on an ad hoc basis, without any precommitment devices. It may be that lawmakers (like the rest of us) cannot always be trusted to make policy decisions that are efficient from a long-run perspective. For example, they may have a tendency to overvalue policy options that produce short-term benefits and delayed or untraceable costs. ${ }^{52}$ Indeed, just such à governmental tendency has been

49. See Michelman, supra note 25, at 1214-18 (discussing the concept of "demoralization costs"). For Graetz's response to Michelman's demoralization cost story, see Graetz, Retro. activity, supra note 9 , at 72 n.77.

50. See Michael J. Graetz, Federal Income Taxation: Principles and Policies 92 (2d ed. 1988). There is evidence suggesting that taxpayers are less willing to comply with the tax laws if they perceive the system to be unfair or inconsistent. See Steven M. Sheffrin \& Robert K. Triest, Can Brute Deterrence Backfire? Perceptions and Attitudes in Taxpayer Compliance, in Why People Pay Taxes: TaX Complance and Enforcement 193 (Joel Slemrod ed., 1992). Goldberg makes a similar point. See Goldberg, supra note 12, at 329.

51. See infra Part V.

52. There is some psychological evidence to support the notion that humans and other animals have a tendency to make decisions that maximize their short-run utility at the expense of their total utility. See George Ainslie, Beyond microeconomics: Conflict among interests in a multiple self as a determinant of value, in THE MULTIPLE SELF: STUDIES IN 
characterized as a type of myopia. ${ }^{53}$ As Jon Elster and others have observed, such myopia (in governments as in people) can be overcome best through some form of precommitment device. 54

Therefore, to reduce the default-premium effect (that is, to minimize $P_{\mathrm{t}}$ ), it might be necessary for the government to precommit to provide full compensation in the event of a change in an incentivesubsidy provision. Whether such a policy would be efficient, again, depends upon the radeoff between the benefits of reduced default premiums and costs of reduced government flexibility. Making a definitive computation of that tradeoff would be an enormous empirical undertaking, which is well beyond the scope of this article. An alternative approach, however, would be to examine how this cost-benefit tradeoff has been made in other, similar contexts. In the following section, I consider the context of government contracts, where an almost identical cost-benefit analysis arises and where we have decided, quite uncontroversially, to precommit to a policy of full transition relief.

\section{B. The Analogy to Government Contracts}

In this section, I develop the analogy between government contracts and incentive subsidies, and I argue that, in both contexts, there are enormous efficiency benefits to the government's keeping its word. To illustrate this point, let's begin with a generic example. Assume that the government determines that some sort of interven-

Rationality and Social Change 133 (Jon Elster ed., 1986); Frank A. Logan, Decisionmaking by Rats: Delay Versus Amount of Reward, 59 J. OF COMP. \& PHYsiological PsYCHOL. 1 (1965). This tendency can be understood as a weakness of will or as the application of an inappropriate discount rate.

53. See generally ELSTER, supra note 1, at 87-103.

54. The benefit of govemment precommitment is a common theme in constitutional theory. See, e.g., LAURENCE TrIBE, AMERICAN Constirumonal Law $\S 9-7$, at 470, 473 (2d ed. 1988) (arguing that the Contract Clause can be understood as a means of precommitting the government); Stephen Holmes, Precommitment and the Paradox of Democracy, in ConstrruTIONALISM AND DEMOCRACY (Jon Elster \& Rune Slagstad eds., 1988) (reviewing the intellectual history of the government-precommitment problem in political theory). In recent years, the benefits of govermment precommitment and the harms of failing to honor such commitments have been formalized by both political theorists and macroeconomic theorists. These models attempt to quantify the theoretical efficiency gains associated with the government's ability to make binding commitments. The classic article in this area, which gave rise to the literature on the "time-consistency" problem, is Finn E. Kydland \& Edward C. Prescott, Rules Rather than Discretion: The Inconsistency of Optimal Plans, $85 \mathrm{~J}$. POL. EcoN. 473 (1977). The default-premium problem discussed in the text is a version of this timeconsistency problem. In developing the time-consistency model, macroeconomists have borrowed from two literatures (game theory and rational-choice theory) that for years have been analyzing implicitly or explicitly the benefits of precommitment by individual and institutional actors. See, e.g., Elster, supra note 1, at 65-76; ThOMAs Schelling, The Strategy of CONFuCT (1960); Robert H. Strotz, Myopia and Inconsistency in Dynamic Utility Maximization, 23 REv. ECON. STUD. 165 (1955). 
tion in the market is necessary to alter taxpayers' investment decisions; suppose, say, that the amount of low-income housing produced by the unregulated private market is found, for whatever reason, to be inadequate. To remedy this situation, the government has several policy options. First, ignoring constitutional constraints for the moment, the government could simply order private parties to build and run the units at their own expense. We can call this option uncompensated government coercion.55 Second, the government could use coercion but then compensate the parties for their costs, an option that we can call compensated government coercion. ${ }^{56}$ Third, the government could build and run the additional housing units itself. That option we refer to as in-house government contracting. Fourth, the government could contract directly with private parties to build and run the units on behalf of the government, which we shall refer to as outside government contracting. Finally, the government could enact a law that promised a payment (for example, in the form of a tax credit) to any taxpayer who invested in low-income housing and who met certain other criteria. The last policy option, of course, is the incentive subsidy.

Each of these policy options has costs and benefits. And the choice of the most efficient (in other words, the most cost-effective) means of increasing the level of investment in low-income housing will depend upon the circumstances. ${ }^{57}$ Consider each policy option in turn. Although it may be difficult to identify the specific circumstances in which uncompensated government coercion would be the optimal tool for increasing the amount of low-income housing, that option is at least conceptually available. The same goes for compensated government coercion. ${ }^{58}$ On the other hand, government contracting (both in-house and outside) is often considered an efficient means of achieving policy goals of this sort. The choice be-

55. This is sometimes called "regulation."

56. This is sometimes called "eminent domain."

57. Cost-benefit analyses of these policy options are common. See, e.g., Richard Layard \& Stephen Glaister, Introduction to CosT-BENEFIT ANALYSIS 1, 3 (Richard Layard et al. eds., 2d ed. 1994) ("Three main methods of [government] intervention are ... regulation, taxes and subsidies, and public direction of what is to be produced, be it via public enterprise or purchase from private firms. Each of these types of government activity can be subject to cost-benefit analysis. ..."). Some commentators argue, however, that the choice among such policy options cannot be captured fully in a traditional cost-benefit analysis but instead require sensitivity to the "cultural" consequences or the "expressive effect" associated with each different policy option. E.g., Richard H. Pildes, The Unintended Cultural Consequences of Public Policy: A Comment on the Symposium, 89 MrCH. L. REv. 936, 940-41 (1991).

58. Compensated govemment coercion might be efficient, for example, during times of military or medical emergency, when there isn't time for options three, four, or five to be implemented effectively. 
tween the two requires the government to address the same sorts of issues that private firms face when they decide whether to perform some function "in house" or whether instead to "contract out."59

Finally, the incentive subsidy also has its place. If we have determined that the total quantity of some asset or activity is being underproduced by the market, it is not difficult to imagine circumstances in which an incentive subsidy would be the most efficient means of increasing the amount of the targeted investment. The principal purported advantage of using an incentive subsidy is that it requires relatively little involvement or supervision by government bureaucrats, and it promotes private, decentralized decisionmaking rather than government-based, centralized decisionmaking. ${ }^{60}$ Similarly, the incentive subsidy might be superior to outside government contracting when contracting costs are high.

Returning to our example, suppose that, after reviewing these options, the government determines that the most efficient way to achieve its low-income-housing goal is to enter into a written contract with a group of private developers and pay them to build the units. Thus, the parties draw up a contract that provides that the developers will build the units, and, in return, the government will pay the developers the agreed amount upon completion of the project. In the absence of contract law to bind the government to keep its word, we can imagine that, after the developers have completed their part of the bargain and built the housing units, the government might decide not to keep its end of the bargain.

Why would the government do such a thing? Because of money. If the government were to renege on the deal, it would get to take the money that had been earmarked for the developers and

59. See Ronald H. Coase, The Nature of the Firm, in 4 EconomaA 386 (1937).

60. See Stanley S. Surrey, Tax Incentives as a Device for Implementing Government Policy: A Comparison with Direct Government Expenditures, 83 HARV. L. REv. 705, 715-19 (1970). Surrey argues that, when it becomes desirable for the government to provide incentive subsidies (which he concedes happens), such subsidies should be provided through direct govermment expenditures rather than through the federal income tax laws in the form of socalled tax expenditures. Surrey's arguments against the use of the income tax law to alter behavior include the following: (a) tax incentives (at least those that take the form of deductions or credits) disproportionately benefit taxpayers with relatively high incomes and (b) by having the expenditures funneled through the tax-writing process rather than the normal expenditure process, we run the risk of implementing conflicting policies and of unnecessarily complicating the tax code. On the other side of that debate, however, some have argued that tax subsidies may be superior to direct subsidies because the former requires less bureaucracy than the latter. See, e.g., Edward A. Zelinsky, Efficiency and Income Taxes: The Rehabilitation of Tax Incentives, 64 TEXAs L. REv. 973, 1010-12 (1986).

That particular debate is beyond the scope of this article, and, for now, I remain agnostic on the question whether incentive subsidies are provided best through tax expenditures or direct expenditures. The framework of this article applies in either case to any type of incentive subsidy, whether it be a tax expenditure or direct subsidy. 
use that money for some other governmental objective. For example, the money could be spent on education or defense or deficit reduction; or it could be redistributed to individual taxpayers in a way that maximizes total social welfare, for example, it could be redistributed from rich real-estate developers to homeless families. Thus, there is a sense in which, once the private developers have made the sunk investments necessary to build the low-income housing units, the socially optimal policy decision might be for the government to break its promise. If the government were to break its commitment in that way, simply because it decided not to follow through with the deal and instead to spend the money on something else, it might be characterized as government opportunism.

If we allowed the government to break its contractual promises without having to pay compensation, such a policy would come at a high cost in terms of increased default premiums in future government contracts and increased disenchantment with the government generally. 61 As with incentive subsidies, whether those costs would outweigh the benefits from the additional flexibility that is gained by permitting the government to disregard its contractual obligations is an empirical question that I do not pretend to answer with any certainty. Nevertheless, consider the following observation: as a general rule, we in fact have adopted a transition policy that requires the government in most circumstances either to keep its contractual promises or pay contract damages. That is, we typically do not allow our government (federal or state) to break its contractual agreements without paying contract damages to the nonbreaching party. If an agency of the U.S. government enters into a contract, it is subject to general principles of contract law. ${ }^{62}$ Likewise, a state

61. According to standard contract theory, the prevention of opportunistic behavior is one of the principal functions of contracts and contract law. See RICHARD A. POSNER, Eco. NOMIC ANALYSIS OF LAW 81 (3d ed. 1986) ("Thus the fundamental function of contract law (and recognized as such at least since Hobbes's day) is to deter people from behaving opportunistically toward their contracting parties, in order to encourage the optimal timing of economic activity and make costly self-protective measures unnecessary." (footnote omitted)); see also John H. Barton, The Economic Basis of Damages for Breach of Contract, $1 \mathrm{~J}$. LEOAL STUD. 277 (1972) (demonstrating how a legally enforceable contract permits parties to overcome the prisoner's dilemma and to achieve joint-wealth-increasing cooperation). Professor Oliver Williamson has written extensively about how markets can respond to overcome the possibility of opportunistic behavior. See Oliver E. Williamson, Markets and Hierar. CHIES: ANAlysis AND ANTITRUST Implications (1975); Oliver E. Williamson, Credible Commitments: Using Hostages to Support Exchange, 73 AM. ECON. REv. 519 (1983).

62. See, e.g., Bowen v. Public Agencies Opposed to Social Sec. Entrapment, 477 U.S. 41, 52 (1986) ("[T]he Federal Govemment, as sovereign, has the power to enter contracts that confer vested rights, and the concomitant duty to honor those rights . . .." (citations omitted)); Perry v. United States, 294 U.S. 330, 351 (1935) ("To say that the Congress may withdraw or ignore [its] pledge, is to assume that the Constitution contemplates a vain promise, a pledge having no other sanction than the pleasure and convenience of the pledgor. This 
legislature will be bound by its contracts, either because of the Contracts Clause in the Constitution, ${ }^{63}$ because of a comparable clause in the relevant state constitution, or because of an explicit waiver of sovereign immunity. Presumably the principal reason we have adopted this policy of holding the government to its contractual commitments is that we have determined implicitly that the costs of the alternative policy outweigh the benefits of such a policy. What's more, that policy is uncontroversial. ${ }^{64}$

If the preceding paragraph presents a satisfactory description of what justifies our decision to apply contract law to the government,

Court has given no sanction to such a conception of the obligations of our Govemment."); Lynch v. United States, 292 U.S. 571, 580 (1934) ("Congress was free to reduce gratuities deemed excessive. But Congress was without power to reduce expenditures by abrogating contractual obligations of the United States. To abrogate contracts, in the attempt to lessen govemment expenditure, would be not the practice of economy, but an act of repudiation."). Note, however, that Congress imposes a clear-statement restriction on its ability to bind itself into the future. See Bowen, 477 U.S. at 52 ("[W]e have declined in the context of commercial contracts to find that a 'sovereign forever waives the right to exercise one of its sovereign powers unless it expressly reserves the right to exercise that power in' the contract." (quoting Merrion v. Jicarilla Apache Tribe, 455 U.S. 130, 148 (1982))). This is sometimes called the "unmistakability doctrine."

The remedy against the federal govemment for breach of contract has developed in stages. Prior to 1855 , a citizen with a monetary claim against the United States could seek redress only through a private bill introduced in Congress. See Jeremy Travis, Note, Rethinking Sovereign Immunity after Bivens, 57 N.Y.U. L. REv. 597, 642 (1982). In 1855, Congress created the Court of Claims and empowered it to hear claims against the United States founded upon any act of Congress or regulation of an executive department or upon any express or implied contract with the United States. See Act of Mar. 3, 1887, ch. 359, $\S \S 1,2$, 5, 24 Stat. 505, 506. Through the Tucker Act, 28 U.S.C. $\S \S 1346,1491$ (1994), Congress responded to the inadequacies of the original Court of Claims legislation. The Act added to that court's jurisdiction claims founded upon the Constitution and claims for liquidated or unliquidated damages not sounding in tort. In addition, district courts were given concurrent jurisdiction of any claims under the statute not exceeding $\$ 10,000$. See 14 Chardes A. Wright et AL, Federal Practice aNd PRocedure $\$ 3657$ (1976). Federal law determines liability under the statute. See Roxfort Holding Co. v. United States, 176 F. Supp. 587, 589 (D.N.J. 1959) ("[T] he matter of liability of the federal govemment is to be determined by federal law.").

63. The Supreme Court addressed the issue of states' immunity from suit early in the development of American jurisprudence, deciding that the Contracts Clause, U.S. Const. art. I, § 10, cl. 1, could defeat a state's claim of sovereign immunity. See Dartmouth College v. Woodward, 17 U.S. (4 Wheat.) 518 (1819); Fletcher v. Peck, 10 U.S. (6 Cranch) 87 (1810). For a variety of reasons, the Contracts Clause fell into disuse until 1977. See United States Trust Co. v. New Jersey, 431 U.S. 1 (1977). See generally, TRIBE, supra note 54, at 613-28 (summarizing the history of Contracts-Clause jurisprudence).

64. Put in these terms, the notion of eliminating the govemment's discretion to break its contracts seems to be in tension with the general conclusion suggested by the Graetz-Kaplow analysis, the conclusion that losses caused by legal transitions, in most cases, should not be compensated by the govemment. As discussed more fully in the following section, however, in the case of the government's opportunistic breach of its own contracts, we have identified a type of govemment risk with respect to which the government is unambiguously the leastcost insurer and a type of transition loss that on efficiency grounds should be compensated. But see Kaplow, supra note 10, at n.54 (acknowledging that the government should pay for goods and services it uses but failing to generalize the point to all govemment contracts or to other legal transitions). 
consider what inferences might be drawn about how we should treat incentive-subsidy provisions. Specifically, consider the following argument: To the extent (a) we are persuaded that incentive subsidies are like government contracts in important ways, ${ }^{65}$ and (b) we are persuaded that, in deciding to make the government generally subject to contract-law principles, we have made the right tradeoff between default-premium concerns and governmentflexibility concerns, the same general rule that we have adopted with respect to government contractual commitments should also be applied to all incentive-subsidy provisions. Under this view, when an incentive subsidy is repealed or substantially reduced, the optimal transition policy would be to provide full transition relief in the form of grandfathered effective dates. ${ }^{66}$

This argument can be generalized. If we can identify any laws or government policies that are analogous to government contracts, the same sort of efficiency argument in favor of a binding precommitment to provide transition relief and against government opportunism can be made. For example, the possibility of opportunistic government behavior is a significant problem in the context of agreements between sovereign nations. The following hypothetical example illustrates the classic problem of one government acting opportunistically toward another:

The government of a developing nation is negotiating with a multinational corporation over an investment project. Eager to have the foreign firm undertake the project, it is prepared to offer handsome incentives over the life cycle of the investment. The firm remains reluctant. It realizes that once its investment is made and the capital is sunk, its bargaining strength diminishes rapidly. The host government would then be in a position - and have the incentive - to impose new requirements (costs) on the firm, which might more than offset the original incentives. Under the circumstances, the multinational will undertake the investment only if it receives substantially larger benefits at the outset. Even then, it will be hesitant to increase the scale of the enterprise, even if it is successful, without further inducements. The host government is perplexed: It would like to promise

65. Note that an incentive subsidy has some of the characteristics of an old common law unilateral contract. See Carlill v. Carbolic Smoke Ball Co., 2 Q.B. 484 (1892).

66. Several previous analyses of tax transitions have recommended a similar transition policy with respect to incentive-subsidy transitions; however, none of them justifies this position by using the sort of efficiency argument that I offer. See BLUEPRINTs, supra note 20, at 176-77; McIntyre, supra note 15, at 13. In addition, as explained below, there are some important differences between the incentive-subsidy transition policy that those authors advance and the one that I advance. 
that no onerous requirements will be imposed in the future but has no way to commit itself or its successor credibly. 67

Thus, the government would benefit from being able to commit itself credibly not to act opportunistically.

Another area of potential government opportunism that does not involve government contracts is public-utility regulation. When a state regulates an electric utility, for example, there is an implicit or explicit understanding that investors in the utility will receive a reasonable rate of retum, and this rate of retum is included in the costs that the utility is allowed to recover in seting its rates. Once investors have sunk a certain amount into the enterprise, however, the state regulatory authority has an incentive to reduce the rates that the utility can charge. This example is another extreme form of government opportunism. ${ }^{68}$

To summarize, in all of these settings, the default-premium concerns discussed in section $\Pi$.A are present. In addition, the analogy to government contracts discussed in this section would suggest that, absent some powerful argument to the contrary, the optimal transition rule in those settings would be for the government to precommit to provide full transition relief in the event of a change in policy. ${ }^{69}$

67. Dani Rodrik \& Richard Zeckhauser, The Dilemma of Government Responsiveness, 7 J. Poly. ANAL YsIS \& MGMT. 601, 602 (1988) (footnote omitted). For a game-theoretic discussion of precisely this type of govemment opportunism in the context of utility regulation, see Glenn Blackmon \& Richard Zeckhauser, Fragile Commitment and the Regulatory Process, 9 Yale J. ON Reg. 73 (1992).

68. See Blackmon \& Zeckhauser, supra note 67. In future research, I plan to analyze a number of specific cases of govemment opportunism in contexts other than federal income tax law and to emphasize the importance of taking into account default-premium effects. For example, one prominent instance of govemment opportunism involves the circumstances surrounding California's Proposition 103, the referendum passed in the fall of 1988 that ordered the rollback in liability and certain other insurance rates in California. This referendum generated an enormous amount of litigation and scholarly attention. See, e.g., Calfarm Ins. Co. v. Deukmejian, 771 P.2d 1247 (Cal. 1989); Steven D. Sugarman, California's Insurance Regulation Revolution: The First Two Years of Proposition 103, 27 SAN DIEGo L. REv. 683 (1990). One could plausibly argue that the insurance companies who were induced to enter the California insurance markets in reliance on the assumption that the prevailing regulatory structure would remain in force (a structure that allowed the insurers to charge premiums that cover their costs) were victims of opportunism at the hands of the State of Califomia as a result of the mandatory rate rollbacks. My concern is that the Califomia voters, in making such a radical change in their insurance-regulatory regime, may have failed to consider adequately the default-premium effects. To be specific, query the extent to which Califomia voters understood and took into account the possibility that, following the rate rollbacks, it would become much more difficult to get insurers to write business in California.

69. Keep in mind, however, that, with respect to all of these examples (including incentive subsidies and government contracts) if it can be shown that the default-premium effect is relatively small, the efficient transition policy may be to provide no transition relief: no grandfather treatment, no contract damages, nothing. 


\section{Incentive Subsidies in the Internal Revenue Code}

The Internal Revenue Code has for many years contained a number of incentive subsidies. The Code currently, for example, includes numerous incentive credits: the low-income housing credit, ${ }^{70}$ the targeted jobs credit, ${ }^{71}$ the enhanced oil recovery credit, 72 the disabled access credit, ${ }^{73}$ the renewable electricity production credit, ${ }^{74}$ the Indian employment credit, ${ }^{75}$ the empowerment zone employment credit, ${ }^{76}$ the research credit, ${ }^{77}$ and the alcohol fuel credit,78 to name just a few. Perhaps the best-known example of an incentive tax credit is the investment tax credit (ITC), which has been used by Congress as an instrument of policymaking off and on for many years and which was repealed in 1986.79 Indeed, all of the credits listed above were designed expressly by Congress to increase the level of taxpayer investment in a specific asset or activity.

In addition to the numerous incentive tax credits, the Code contains many deductions and exclusions that could easily be understood as incentive subsidies. For example, the Code permits accelerated-depreciation deductions for certain types of tangible assets that are either used in a trade or business or held for the production of income. ${ }^{80}$ Furthermore, the Code gives taxpayers the

70. I.R.C. $\$ 42$ (1996).

71. I.R.C. $\S 51$ (1996).

72. I.R.C. $\S 43$ (1996).

73. I.R.C. $\S 44$ (1996).

74. I.R.C. § 45 (1996).

75. I.R.C. § 45A (1996).

76. I.R.C. § 1396 (1996).

77. I.R.C. $\S 41$ (1996).

78. I.R.C. $\S 40$ (1996). These credits are combined into a general-business credit for the purpose of computing how much of each credit will be allowed in a given year and in carryback and carryover years. See I.R.C. §§ 38(b)-39 (1996).

79.

The [investment] credit was first enacted in 1962 in connection with that year's liberalization of depreciation rules to stimulate purchases of new machinery and equipment to bolster a lagging economy. Since 1962, the credit has been utilized as an instrument of fiscal policy. The investment credit was increased in 1964, removed in 1966, reinstated in 1967, repealed in 1969, reinstituted in 1971, temporarily increased in 1975, "permanently increased" in 1978, reduced in 1982 and repealed once again in 1986. Although the repeal of the investment tax credit was used in 1986 to finance a large share of the revenue cost of reducing the top corporate tax rate from 46 to 34 percent, its history suggests that it would be foolish to regard the investment tax credit as a dead letter for the future.

GRAETZ, supra note 50, at 407.

80. Taxpayers have long been able to take depreciation deductions to account for the "exhaustion, wear and tear (including a reasonable allowance for obsolescence)" of assets used in a trade or business or held for the production of income. I.R.C. $\S 167$ (1996). In 1981, Congress enacted the Accelerated Cost Recovery System (ACRS), which replaced the 
option to "expense" (that is, to deduct immediately) the cost of investing in specific types of tangible business property. ${ }^{81}$ Taxpayers who invest in mines, oil and gas wells, and other natural deposits get the benefit of "percentage-depletion" deductions, which can produce a large subsidy for such investments. ${ }^{82}$ A number of provisions in the Code also provide accelerated amortization for specific types of investments, for example, the five-year amortization deductions for the cost of pollution-control facilities ${ }^{83}$ and for certain research-and-development expenditures ${ }^{84}$ and the seven-year amortization deductions for certain qualified reforestation expenditures. ${ }^{85}$ In addition, the home-mortgage-interest deduction, ${ }^{86}$ the charitable-contribution deduction,, 87 and the exclusion for interest received on state and local bonds ${ }^{88}$ all could be understood as incentive subsidies. Indeed, all of these deductions and exclusions (as well as the credits listed above) are designed to increase taxpayers' level of investment in certain types of assets and activities and thus easily can be understood as substitutes for direct government contracting. ${ }^{89}$

With respect to any of these tax provisions, the framework of this article suggests that Congress should adopt a policy of providing guaranteed grandfather meant should the provisions be repealed or substantially reduced. At this point, it might be argued that, because every aspect of the tax laws affects taxpayers' incen-

pre-1981 depreciation rules with respect to most tangible property. The accelerated deductions permitted under ACRS had the effect of increasing the after-tax rate of retum on investment in qualifying depreciable property, thereby giving taxpayers an incentive to increase their level of investment in such assets. In fact, when the Tax Reform of 1986 replaced the ACRS with the Modified Accelerated Cost Recovery System (MACRS), one of its principal motivations was to reduce the effect on investment incentives. See 2 U.S. TREASURY DEPT., REPORT TO THE PRESIDENT, TAX REFORM FOR FAIRNESS, SimplictTy AND ECONOMIC GROWTH 154-57 (1984) ("The low or negative effective tax rates on ACRS property and the tax deferral resulting from accelerated depreciation allowances distort investment decisions in a variety of ways."). See generally GRAETZ, supra note 50, at 392 ("[D]epreciation allowances have long been used to adjust the overall level of investment in plant and equipment for fiscal policy reasons.").

81. See I.R.C. $\S 179$ (1996). A limit is placed on the total amount a taxpayer can expense under $\S 179$ in a given tax year. The current limit is $\$ 17,500$. See I.R.C. $\$ 179$ (b)(1) (1996).

82. See I.R.C. §§ 611-14 (1996).

83. See I.R.C. § 169 (1996).

84. See I.R.C. § 174(b) (1996).

85. See I.R.C. § 194 (1996).

86. See I.R.C. $\S \S 163(\mathrm{a}),(\mathrm{h})(3)$ (1996).

87. See I.R.C. $\S 170$ (1996).

88. See I.R.C. § 103 (1996).

89. For an extensive list of incentive-subsidy provisions, see generally JoINT COMM. ON

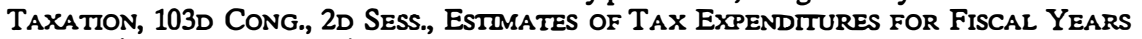
1995-99 (Comm. Print 1994). 
tives to some extent, all tax laws can be characterized plausibly as subsidies. On this theory, it is misleading to analyze a relatively small set of credits, deductions, and exclusions. Fair enough. Whenever there is an inconsistency in the tax treatment of two comparable types of investments there will be an effect on taxpayers' investment decisions, and that inconsistency can be called a subsidy or a penalty, depending on one's starting point. For example, the introduction of the income tax itself might alter taxpayers' decisions regarding how they will allocate their resources as between work and leisure. Thus, if the substitution effect were to overwhelm the income effect, the income tax could, in a sense, be seen as a subsidy of leisure.

Applying the term "incentive subsidy" to all tax provisions, however, would render the term empty and unhelpful. The object of this Part of the article is to identify a class of tax laws that most resemble a contract because such provisions give rise to the most serious default-premium problems. In other words, my contention is that incentive-subsidy provisions such as the ones listed in the text have much greater incentive effects than do most changes in marginal income tax rates, unless the rate changes are extremely large. 90

As I explain more fully in Part IV below, however, to the extent incentive effects become a problem in connection with tax-rate changes and other broad-based types of tax transitions, the arguments in this section would apply. In such situations, the use of transition relief should at least be considered. In connection with changes in income tax rates, however, incentive effects and thus default premiums are probably not the pivotal issues. Rather, in those contexts, distributional concerns become determinative.

90. It is still true, however, that some of the provisions I have listed as incentive tax subsidies might be better characterized differently. For example, the home-mortgage-interest deduction may be understood best, not as being designed to induce higher levels of home ownership, but rather as being designed to reduce the effective tax rate on middle- and highincome taxpayers. If the latter characterization is more accurate, and the home-mortgage interest deduction is not primarily an incentive subsidy, we may be less concerned about default-premium effects in the event of a repeal. In my view, this deduction (more so than most provisions) has substantial incentive and distributional effects.

Interestingly, these two effects are importantly related; they pull in opposite directions. If the deduction has a large incentive effect (causing more taxpayers to buy homes) the distributional effect may be diminished because of the putative tax that results when the taxinduced incentive increase in demand for housing produces higher housing prices. 


\section{Potential Objections to Guaranteed GRANDFATHERING}

\section{A. The Graetz-Kaplow "Government-Risk" Theory}

The conclusion from Part II - that repeals of or reductions in incentive subsidies should be accompanied by full transition relief - contradicts the Graetz-Kaplow government-risk theory. The Graetz-Kaplow position is simple yet powerful: Just as the government does not generally provide insurance to private investors for market contingencies (such as the risk of a change in consumer preferences or a change in the cost of some input), it should not insure them against the risk of change in government policy. Under this view, market risk and government risk are indistinguishable, and, to achieve efficiency, investors must be forced to take both types of risk into account when making investment decisions. Therefore, the efficient transition policy in terms of its effects on incentives would be to provide no transition relief. Under such a policy, taxpayers making investment decisions would be induced to take into account not only the risk of changes in inflation rates or in the business cycle but also changes in the federal income tax laws.

Kaplow summarizes this argument as follows: "If one accepts the common belief that government relief of market risk is generally undesirable because the market usually operates efficiently, or at least that government relief would be no better, then one should conclude that mitigation of government risks is economically unjustifiable." 91 He goes on to argue that "new rules" (such as new federal income tax provisions) should be made immediately applicable to all pretransition investments with no grandfather treatment.92 Indeed, Kaplow would provide no transition relief whatever, as "[t]ransitional relief constitutes an externality that disrupts the market's response to the risk imposed by uncertainty concerning future government action."93

Graetz, who made essentially the same point nine years earlier, states the argument in a way that stands in stark contrast to the thesis of this article. He contends that a taxpayer's reliance on an existing tax-law provision cannot form the basis of an argument for transition relief precisely because, in Graetz's view, the contract analogy is inapt. This analogy supposedly fails because taxpayers

91. Kaplow, supra note 10, at 535.

92. See id. at 587 ("[Tax subsidies] typically should not be designed so as to incorporate grandfathering, because it generally is undesirable.").

93. Id. at 551 . 
should take into account the possibility that tax law will change over time; therefore, reliance on any given tax provision "should be tempered by the subjective probability that the law will be altered."94

In the context of government contracts and incentive-subsidy provisions, however, the Graetz-Kaplow analysis does not produce a general rule against transition relief. ${ }^{95}$ This is because the risk that the government will breach a contract or repeal an incentivesubsidy provision without providing transition relief differs from market risks. One of the principal functions served by any contract is to allocate risks between the contracting parties. If the agreement is fully and efficiently specified, each of the various risks inherent in the transaction will be allocated to the least-cost insurer. The least-cost insurer will be either the party who can eliminate the risk at lowest cost or, if the loss is unpreventable, the party who can most efficiently allocate the unpreventable risk either by purchasing insurance or by self-insuring. In addition to allocating risk, however, the contract serves another important function: to prevent either party from acting opportunistically. This function, too, can be put in risk-allocation terms; that is, the fully and efficiently specified contract would allocate the risk of opportunism to the opportunist. ${ }^{96}$ Thus, applying the Graetz-Kaplow framework, if failure to provide transition relief (either in the form of contract damages or grandfather treatment) would amount to opportunism on the part of the government, efficiency would require that such relief be provided.

\section{B. The Distinction Between Opportunistic and Nonopportunistic Legal Transitions}

What if Congress decides to repeal an incentive subsidy nominally retroactively, but for nonopportunistic reasons? That is, the government repeals the provision not because, having induced the desired level of taxpayer investment, it now wants to use on other projects. Rather, Congress repeals the subsidy primarily because it has determined that the subsidy was a mistake from the beginning. For example, Congress learns that the targeted investment (lowincome housing, nuclear power, oil-and-gas exploration, or

94. Graetz, Consumption Tax, supra note 26, at 1651.

95. Below I discuss one type of transition (the mistake case) where the government-risk argument, on incentive grounds, may call for no transition relief.

96. See PosNer, supra note 61 , at 79-81. 
whatever) causes more social harm than good, and therefore the subsidy never should have been enacted.

In the nonopportunism situation (which I sometimes refer to as the government-mistake case), the government-risk theory would call for a transition policy of no relief because such a policy would place the risk of transition losses resulting from nonopportunistic changes in policy directly on investors. Kaplow illustrates this conclusion with two simple examples, one involving the taking of private land for public use and the other involving the banning of a product:

Suppose there is a substantial chance that land will be taken and leveled for a highway and that a product will be found hazardous and will therefore be banned. Should these events occur, investments in improvements on the land and in manufacturing equipment to produce the product would be rendered worthless. Accordingly, ex post, it might well have been socially preferable for the landowner and the manufacturer not to have made the investments in the first place. ${ }^{97}$

Note how these examples of legal transitions differ from transitions owing to government opportunism. In the opportunism case, it is efficient to place the risk of opportunistic behavior on the opportunist; so it is efficient to place the risk of government opportunism on the government. In the case where the government discovers new facts revealing that its original decision was a bad idea, however, whether the risk of transition losses should be left on individual investors to allocate through private markets or should be borne by the government via transition relief turns on the answer to the following question: Who is the more efficient bearer of the risk of government mistakes, the government itself or the private parties? ${ }^{98}$ Kaplow provides an elaborate argument for why efficiency generally requires that government risk be borne directly by private parties rather than by the government, to optimize the private parties' ex ante investment incentives.99 That argument is most persuasive, however, with respect to certain types of situations. For example, consider the case of the product ban mentioned in the quotation above. In that situation, one could quite plausibly argue that the product manufacturer should be required to bear the risk that its product might someday be banned by the government

97. Kaplow, supra note 10, at 529 (footnotes omitted) (emphasis added); see also id. at 551,573 (drawing a distinction between mistake cases, where nominal retroactivity is appropriate, and change-of-circumstance cases, where nominal prospectivity is appropriate).

98. The allocation of the risk of a government mistake presents issues similar to those that gave rise to the contract doctrines of mistake, impossibility, and frustration. See FRIEDRICH KESSLER ET AL., CONTRACTS ch. 8 (1986).

99. See Kaplow, supra note 10, at 536-50. 
for health-and-safety reasons. After all, it is the manufacturer who typically has the best access to information regarding the relative safety of the products it plans to produce. Further, we want the manufacturer, when deciding whether to manufacture a given product, to consider all of the possible health-and-safety issues involved, and we do not want the manufacturer to externalize potential hazards onto the government. ${ }^{100}$ Put simply, it is easy to believe that a product manufacturer is the least-cost insurer with respect to this type of legal transition.

It is less plausible, however, that taxpayers are the least-cost insurers against the risk that the government will repeal a mistaken incentive subsidy. In that situation, one would expect the government to be the superior insurer; we typically want the government to bear the risk that its decision to enact a given subsidy will prove to have been a mistake. Additionally, making the government bear the risk that the incentive subsidy will turn out to be a bad idea will induce lawmakers to engage in a more careful cost-benefit analysis before enacting the incentive subsidy in the first place. Thus, the government-risk analysis does not unambiguously favor a transition policy of no relief in the context of incentive-subsidy transitions that are cases of government mistake; it may even favor a transition policy of full ransition relief in such situations.

This conclusion is consistent with the reatment of nonopportunistic government mistakes in the government-contract setting. If the government enters into a contract that it later determines to be a bad idea, it may decide not to make such contracts in the future. It still, however, must comply with the old contract or else pay damages. That is, contract law applies even when the government makes a bad deal. Presumably, our decision to apply such a rule in the context of government contracts and to maintain that rule for so many years derives from our conclusion (albeit implicit) that the least-cost insurer of government opportunism is the government. To the extent that the same reasoning applies to the case of incentive-subsidy provisions, the optimal transition policy therefore is to provide guaranteed grandfather protection, irrespective of the government's reason for enacting the change.

All of the foregoing arguments apply as well when the repeal of the incentive subsidy or the breach of a government contract is motivated, not by the government's discovery of new facts, but by a change in the government itself. For example, imagine that Con- 
gress were initially controlled by one of the dominant political parties, during which time a number of incentive-subsidy provisions designed to increase the level of taxpayer investment in certain activities (for example, low-income housing or research and development) were enacted. Then comes a dramatic shift in the political landscape; the minority party gains control of the legislature and decides to repeal the newly enacted incentive subsidies. In such a situation, the newly constituted legislature, according to the argument developed in Part $\Pi$, should be bound to provide grandfather treatment to those who invested in reliance on the old incentive subsidies, so as to minimize the default-premium effect as well as general disenchantment with the government for not keeping its promises. This conclusion may be most intuitive in the case of government contracts. If, for example, the old Congress were to enter into contracts with private parties or with other governments, the new Congress should not be able to terminate those contracts at will without providing compensation. As I have already discussed, we do in fact require our government to comply with basic contract principles even when the there is a shift in political power. ${ }^{101}$ One of the principal goals of this article is to emphasize that point and to suggest that the same presumption should be applied to all incentive subsidies.

Professor Kaplow contends that, when a transition is motivated by a change in the government or by a change in the voters' preferences (which amounts to the same thing), the efficient transition policy is indeterminate. ${ }^{102}$ In one sense, I agree. As argued above, whether binding the government to its promises (promises in the form of explicit contracts or incentive subsidies) will prove efficient is ultimately an empirical question on which there is essentially no direct data. However, our decision to adopt such a rule in the context of government contracts is uncontroversial presumably because of the default-premium concerns and government-legitimacy concerns discussed in Part $\Pi$. The same rule should apply to incentive subsidies in the tax code.

101. That the government generally must comply with its contracts does not mean that one legislature has unlimited power to bind future legislatures. For example, the Supreme Court has long held that a current state legislature cannot contract to constrain a future legislature's police power or power of eminent domain. See Stone v. Mississippi, 101 U.S. 814 (1880). States, however, frequently enter into contracts restricting their future taxing power. These are called tax abatements, and they are a common method by which states compete for corporate relocations. See Andy Zipser, Civil War, Round Two, BARRON's, April 3, 1995, at 23 (discussing the growing use of tax abatements by states to lure corporations into the state).

102. See Kaplow, supra note 10, at 573. 
One could plausibly argue that an exception to this transition policy should be made in the case of incentive-subsidy transitions that are motivated primarily by the desire to redistribute wealth from the former beneficiaries of the subsidy to the federal fisc. As Graetz puts the point: "Grandfathering a change which is motivated by a desire to increase the tax burden on the class of persons who have enjoyed a tax incentive is much like passing a law to redistribute wealth and requiring compensation to those from whom the wealth was distributed." 103 In such a situation, we face a tradeoff between incentive concerns and distributional concerns.

Again, the government-contract example is instructive. We would not generally allow the government to walk away from a contract with a private party without paying damages, even if the private party is wealthy and the contract damages (instead of being paid as contract damages) could be redistributed to more deserving souls. Redistribution of that sort usually is done with a broader brush, through broad-based tax-rate increases and direct subsidies. Such broad-based ransitions do not give rise to the same degree of default premiums that would accompany an opportunistic breach of contract or retroactive incentive-subsidy transition. ${ }^{104}$

\section{The Slippery-Slope Objections}

Another set of objections to the transition policy of providing full relief in cases of incentive-subsidy ransitions is based on the claim that such a policy contains no logical limits and is therefore unworkable. As I argue in this section, however, these objections can be resolved by reference to the government-contract example.

The first slippery-slope objection is this: If one is persuaded that the default-premium effect presents a serious concern, why should transition relief be provided only to the "nominal beneficiaries" of the incentive subsidy, that is, only to the taxpayers who claimed the credit, deduction, or exclusion on their tax returns. Shouldn't transition relief be provided to all parties who made investments in reliance on the subsidy, including those who benefited

103. Graetz, Retroactivity, supra note 9, at 82 .

104. Still, Graetz's general point regarding redistributive tax transitions is well taken, and it is an important point for those incentive-subsidy transitions that affect large classes of taxpayers and that begin to have the characteristics of a nonsubsidy tax transition, such as rate increases. See infra Part IV and supra note 9. 
from the subsidy only indirectly? Professor Graetz illustrates this criticism with the following example:

[I]n the case of an exemption for state and local bond interest, advocates of compensation to losers would compensate only the holders of tax-exempt bonds. It has not been suggested, however, that issuers of tax-exempt bonds, who may well have structured their financing plans on the expectation that exempt status would continue into the future, are entitled to continuation of the tax exemption because of their "reliance" interest. Nor has it been argued that those who demanded or supplied substitutes, on the assumption that the exemption would continue, should also be protected. If the faimess of change depends upon individual reliance, all persons who might be expected to have altered behavior because of a particular tax rule must be protected. ${ }^{105}$

There are a number of responses to this objection. First, it is true that indirect beneficiaries of an incentive subsidy can suffer transition losses when the subsidy is repealed; it is also true that grandfathering the repeal of the provision will not necessarily provide ransition relief for those parties. Therefore, if the incentive subsidy has had a desirable effect on the incentives of those indirect beneficiaries and an effect that is sufficiently large that Congress wants to protect it, transition relief (perhaps in the form of direct compensation) may be appropriate. Such a policy would be fully consistent with the thesis of this article. What is more likely, however, is that the incentive benefits are relatively small when compared to the costs of the compensation system that would be required. (Imagine the difficulty that Congress would encounter attempting to evaluate the validity of the claims brought for compensation by all the parties who purport to be indirect beneficiaries of a given incentive subsidy that is slated for repeal.) Thus, the efficient transition policy with respect to incentive-subsidy provisions probably is full transition relief to nominal beneficiaries of the subsidy in the form of grandfathered effective dates and no relief for indirect beneficiaries.

This transition policy would be consistent with the rules that apply to government contracts. As discussed in Part II, when the government breaches a contract it must pay damages to the nonbreaching party. It normally will not be required, however, to pay damages to third parties who suffer losses as a result of the breach. Under basic principles of contract law, for a nonparty to a

105. Graetz, Consumption Tax, supra note 26, at 1651. 
contract to recover damages, it must qualify as a third-party beneficiary. 106

A second slippery-slope objection to a transition policy of guaranteed grandfather treatment is based on the following claim: There is no meaningful distinction between incentive subsidies that have been enacted and those that have been proposed but not enacted. For example, to support his claim that "[i]ndividual reliance on the status quo simply will not suffice as a basis for compensation or grandfathered effective dates," Graetz offers the following hypothetical:

Consider a situation in which the President announces a program to subsidize a certain activity through income tax deductions or credits, for example, tax credits for the insulation of homes. Members of Congress crucial to the passage of the legislation make speeches embracing the proposal. A company engaged in the manufacture of home insulation materials, in reliance on these statements, purchases additional machinery to manufacture insulation. If the legislation is never enacted and the manufacturer loses, should his losses be compensated or should he be otherwise protected? Does the fact that the legislation passes both Houses of Congress but is not signed by the President alter the result? Why, then, is the repeal of legislation enacted one year earlier thought to present a more compelling case for compensating reliance? Should those who failed to invest in insulation on the assumption that the legislation would not be enacted also be protected?107

This argument, too, seems to miss the mark. First, although Graetz intimates to the contrary, it may be the case that Congress will sometimes want to use public promises of future, yet-to-beenacted incentive subsidies as a means of altering taxpayers' incentives. If so, we should consider the costs and benefits of providing transition relief to investors who make investments in reliance on such promises. However, because of the administrative costs that would accompany an effort to identify those who suffered such reliance losses, the optimal scope of transition relief probably is limited to compensating those who have made investments in reliance on the subsidy only after the subsidy has been enacted. This limitation would be analogous to the doctrine of "consideration" in contract

106. See generally KESSLER ET AL., supra note 98, at ch. 11 (reviewing the law of thirdparty beneficiaries). It is worth noting that in recent years courts have been increasingly willing to allow claims brought by parties alleging to be third-party beneficiaries of government contracts. See id. at 1384-418; see also Anthony Jon Waters, The Property in the Promise: A Study of the Third Party Beneficiary Rule, 98 HARv. L. REv. 1109 (1985) (connecting the development of third-party-beneficiary doctrine in the context of government contracts to the rise of "new property" concepts pioneered by Charles Reich).

107. Graetz, Retroactivity, supra note 9, at 78. 
law, which serves the function of providing evidence of the parties' intent to be bound. ${ }^{108}$

\section{The Analogy to Long-Term and Short-Term Contracts}

Part II's use of the contract analogy and its argument in favor of guaranteed grandfather treatment for incentive-subsidy provisions may also be subject to the following attack: Even if one concedes that an incentive-subsidy provision has important characteristics that are similar to the characteristics of a government contract, the contract analogy itself does not provide an efficiency-based justification for guaranteed grandfathering. According to this argument, an incentive subsidy that is accompanied by a guarantee of grandfather protection is akin to a long-term contract; whereas, an incentive subsidy without such a guarantee is akin to a short-term contract. In present-value terms, the argument goes, such contracts are equivalent. Thus, the effect of transition policies on default premiums is irrelevant to the question whether Congress should promise to provide transition relief. That question should instead be answered on different grounds.

This argument is derived from the article on tax transitions by Professors Ramseyer and Nakazato. ${ }^{109}$

[T]hink of tax legislation as a "contract" between investors and the state, and consider what the "price" of this contract would be. The contractual analogy follows from Congress's offering tax benefits in return for taxpayers' agreements to make specified investments. By urging Congress to abandon grandfather clauses, Graetz and Kaplow argue that the optimal contract is one with a short (and indefinite) term: The state promises to keep the tax benefits only until it finds a way to improve the law. If the state instead vows to grandfather existing projects, it adopts a long-term contract: a promise to continue the benefits for the life of the project. Note, however, that the price of the contract will be the same in both cases. After all, risk-neutral investors primarily care about the expected net present value of the

108. See KESSLER ET AL., supra note 98 , at ch. 5.

109. Ramseyer and Nakazato, it turns out, favor guaranteed grandfather treatment for incentive-subsidy transitions but for reasons different from those argued here. They rely on the following theory: that a policy of promising grandfathering to those who rely on incentive-subsidy provisions would reduce the amount of social resources spent lobbying against the repeal of tax subsidies in situations in which such a repeal would be efficient. See Ramseyer \& Nakazato, supra note 12, at 1171-72; id. at 1174 ("Under a tax-guaranteed regime, investors will not care whether Congress revokes their tax-favored status; under a taxcontingent strategy, they will care dearly. Accordingly, under the former they will lobby and bribe less than under the latter, and to the extent that happens, society gains."). In this article, I ignore the effect of alternative transition policies on lobbying expenditures. Ramseyer and Nakazato's arguments with respect to that question, though, seem facially plausible and therefore provide another justification for a credible government commitment to grandfather any changes to an incentive-subsidy provision. 
tax benefits they gain from an investment; they will rarely care whether Congress packages benefits of equal net value in long- or short-term contracts. ${ }^{110}$

This argument, however, misunderstands the significance of the contract analogy. First, any incentive subsidy that provides benefits to taxpayers over a period of years rather than all at once (which I have called an "installment subsidy") cannot be akin to a shortterm contract. Such an incentive subsidy is either akin to a longterm contract (if the government commits to provide transition relief should the subsidy be repealed) or it is not (if the government does not so commit). Thus, at least with respect to installmentincentive subsidies, the relevant question is whether the benefits of such a commitment exceed the costs. Part II argues that there is reason to believe the answer typically will be "yes."

Second, if the government were to adopt a policy of zero transition relief (that is, the law could be changed at any time and the change would be made nominally retroactive) such a situation would not be analogous to a government contract at all, short-term or long-term. It would instead be analogous to an empty, unenforceable government promise. Part II illustrates how such promises, in the absence of any precommitment on the part of the government, would give rise to large default premiums, as taxpayers would come to expect opportunism on the part of the government. For reasons that are not fully explained in the article, however, Ramseyer and Nakazato implicitly assume that the reduction in default premiums resulting from a policy of guaranteed grandfathering is never greater than the loss of government flexibility but rather that the two effects are always perfectly offsetting. That is extremely unlikely. Indeed, if it were so, in the governmentcontract setting, we would generally be indifferent as to whether the government kept its contractual promises or not. To the contrary, in the context of government contracts, we have decided to assume that default-premium concerns trump government-flexibility concerns; hence, the application of contract law to the government.

\section{Other Types of TAX Transitions}

\section{A. The Correction of Obvious Legislative Errors}

Parts II and III argued that, with respect to the repeal of incentive subsidies, the optimal transition policy would be one that promises full transition relief in the form of grandfathered effective 
dates. It may be efficient, however, to permit an exception to this policy in a narrow class of cases in which the repealed or revised provision contains an obvious error. ${ }^{111}$ The exception would take the form of the following transition policy: If there is a provision in the Code that some taxpayers interpret in a manner that generates extraordinarily large tax savings, and if there is strong evidence that Congress never intended the provision to be interpreted in that manner, then, if the provision is repealed or amended to eliminate the taxpayers' aggressive interpretation, the change will apply nominally retroactively. Thus, taxpayers who take advantage of such a provision do so at their own risk, and any tax savings they enjoy because of it will be recaptured retroactively if the provision is later repealed. 112

Such a rule would increase the incentive for taxpayers (and tax counsel) to interpret the tax laws in good faith. ${ }^{113}$ One might object to this policy on the ground that most individual taxpayers are relatively unsophisticated and therefore cannot be expected to distinguish the tax loopholes that Congress intends from the ones it does not. If that is a substantial concern, the transition policy proposed in this Part could be narrowed even further to apply only to situa-

111. The distinction that I draw between obvious legislative error (discussed in this section) and government mistake (discussed in section III.B above) is akin to the distinction in contract law between the treatment of obvious typographical errors in written contracts and the treatment of unilateral mistakes.

112. McIntyre suggests something similar to this policy: "When Congress amends the Code to correct what is generally regarded as an unintended defect in the statute, no special transition rules are justified." McIntyre, supra note 15 , at 13 . The transition policy that I would apply to corrections of obvious errors, in contrast, would entail a special transition rule. It would apply the correction nominally retroactively. Also, McIntyre does not discuss the difficulty of distinguishing transitions that are corrections of obvious errors from those that are (to use my term) "opportunistic." Kaplow contends that arguments for an obviouserror exception of the sort I have described serve merely to illustrate the benefits of his proposed rule: nominal retroactivity for all transitions. See Kaplow, supra note 10, at 608-09. In my view, the obvious-error exception is understood best as an exception, not as a rule.

113. Note that the Code already contains specific penalty provisions designed to induce taxpayers to interpret the tax rules reasonably and in good faith. For example, the taxreturn-accuracy penalty, found in $\S 6662$, imposes a $20 \%$ penalty on any portion of an underpayment of tax that is attributable to, among other things, negligence or disregard of rules or regulations or a substantial understatement of income tax liability (in the absence of "substantial authority" for the taxpayer's position). See I.R.C. § 6662(b) (1996). Note, however, that no accuracy-related penalty is imposed under this section with respect to any portion of the underpayment for which the taxpayer can establish that she had a "reasonable cause" and that she acted in good faith. See I.R.C. \$ 6664(c) (1996). Thus, the accuracy penalties would not apply in the context of an obvious legislative error, as I have defined that term. That is, when Congress has unintentionally but unambiguously enacted a loophole, there is no question that the taxpayer has reasonable cause for her position, as that term is understood by the Service and by the courts. In this section, however, I am suggesting that, although taxpayers who take aggressive positions in reliance on obvious legislative errors do not risk accuracy-related penalties, if such provisions are then repealed by Congress, the repeal should be made nominally retroactive. 
tions in which the taxpayer can be expected to have sophisticated tax counsel. For example, it could be limited to tax transitions affecting corporations.

Distinguishing error-correction transitions, which will be applied nominally retroactively, from incentive-subsidy transitions, which will give rise to full transition relief in the form of grandfathered effective dates, will sometimes present a challenge. Still, there may be criteria that can assist in drawing the distinction. For example, perhaps there should be a presumption that the errorcorrection exception will not apply if the provision being repealed has been in effect for a number of years. Thus, if Congress decides to repeal a provision that has been in the Code for many years, the repeal clearly should not be made nominally retroactive to the earliest years in which the provision was in effect. This gives Congress an incentive to make such corrections as soon as the error is discovered. Such corrections occur quite frequently in tax legislation, and they are often packaged together in so-called Technical Corrections bills. Furthermore, perhaps there should be a rebuttable presumption, if not a guarantee, that such a repeal would be grandfathered.

In addition, if the Treasury Department issues regulations or the Internal Revenue Service issues a ruling interpreting a given Code section in a manner consistent with taxpayers" "aggressive" interpretation, and Congress later repeals that section or amends it in a way inconsistent with Treasury's interpretation, the repeal should not be applied nominally retroactively. Instead, the repeal should be grandfathered or at least made nominally prospective. By the same token, if the Treasury Department issues an interpretation of a Code section that is inconsistent with taxpayers' aggressive interpretation, and Congress later changes the section to close the loophole, there is an even stronger argument for making that change nominally retroactive, at least retroactive to the date on which the Treasury interpretation was first issued and perhaps retroactive to the date of enactment of the original provision.

Admittedly, enforcing a general transition policy of grandfathering incentive-subsidy transitions while simultaneously maintaining a policy of nominal retroactivity for transitions designed to close obviously unintended loopholes will create difficulties. Taxpayers lobbying Congress for transition relief in connection with the repeal of some provision will inevitably argue that their provision falls under the rule rather than the exception. Although drawing lines in some cases may prove difficult, the gain from line drawing probably ex- 
ceeds the cost, especially if the exception for legislative corrections is kept extremely narrow and is applied only in egregious cases.

This transition policy for situations involving corrections of obvious legislative errors can be seen in the following example. As part of the Tax Reform Act of 1986, Congress enacted an estate-tax provision that was designed to create an incentive for owners of corporations (more precisely, for the estates of deceased corporate shareholders) to sell their stock in the corporation to the company's employees rather than to outsiders or the corporation. ${ }^{114}$ Thus, the provision created a deduction for half of the proceeds of "any sale of employer securities by the executor of an estate" to "an employee stock ownership plan [ESOP]."115 The problem, however, was that the provision contained no requirement that the decedent have owned the stock in question to qualify for the special ESOP deduction. As a result, soon after the enactment of this provision, many executors of large estates immediately began purchasing stock in corporations that had ESOPs and then immediately reselling the shares to the ESOPs. Because the estates could then deduct half the sale proceeds on their estate-tax return, the estates were able to reduce their tax burdens dramatically.

Congress was taken by surprise. It had clearly not intended the use of the ESOP deduction in connection with shares purchased after the death of the decedent shareholders. Evidence of Congress's surprise can be seen in the contrast between Congress's initial projections regarding the amount of tax revenue that the ESOP provision would cost (approximately $\$ 300$ million over five years) and the later projections, once Congress learned how taxpayers were interpreting the provision (upwards of $\$ 7$ billion). ${ }^{116}$ Therefore, in February 1987, only a few months after its enactment, Senator Bentsen from Texas introduced an amendment to the provision, inserting language requiring that, to qualify for the estate-tax deduction, the securities sold to the ESOP must have been "directly

114. See Staff of Jont Comm. on Taxation, 99th Cong., 2D Sess., Tax Reform Proposals: Tax Treatment of Employee Stock Ownership Plans (ESOPs) 37 (Comm. Print 1985). See generally United States v. Carlton, 114 S. Ct. 2018 (1994).

115. Tax Reform Act of 1986, Pub. L. No. 99-514, 100 Stat. 2085, 2514, amended by Omnibus Budget Reconciliation Act of 1987, Pub. L. No. 100-203, § 10411(a), 101 Stat. 1330, 1330-433 (repealed 1989).

116. See 133 Cong. REC. 4145, 4293 (1987). Senator Bentsen stated that "Congress did not intend for estates to be able to claim the deduction by virtue of purchasing stock in the market and simply reselling the stock to an ESOP ... and Congress certainly did not anticipate a $\$ 7$ billion revenue loss." Id. at 4294. 
owned" by the decedent "immediately before death." And this amendment was passed in December 1987..$^{117}$

What is most interesting about this tax transition, however, is that Congress made the amendment, which was enacted in December 1987, nominally retroactive to apply to transactions in 1986 as well as those in 1987.118 This example of nominal retroactivity is arguably consistent with the transition policy described above. It is also worth noting the Internal Revenue Service's response to the initial enactment of the ESOP provision. On January 5, 1987, only a few months after the provision was enacted, the Service announced that "[p]ending the enactment of clarifying legislation," it would interpret the original provision as if the amendment had been included from the start and thus would allow the ESOP deduction only for sales of securities that had been owned by the decedent at the time of death. ${ }^{119}$ Given this announcement by the Service, the argument for applying the amendment at least to all of 1987 is extremely strong. Moreover, if one agrees that the taxpayers' interpretation of the provision clearly was not what Congress intended, the argument for applying the amendment to 1986 is strong as well.

It was the constitutionality of this transition rule that was at issue in United States v. Carlton. ${ }^{20}$ The taxpayer in Carlton had taken advantage of the estate-tax loophole created by the original ESOP-deduction provision. In December 1986, the estate of Mr. Carlton had purchased stock in a corporation only to resell the stock two days later to the corporation's ESOP, thereby generating a huge estate-tax deduction. Although the taxpayer sold the stock to the ESOP at a loss, the transaction produced an enormous profit after taxes for the taxpayer once the ESOP deduction was taken into account. ${ }^{121}$ When the Internal Revenue Service, applying the amended version of the statute, disallowed the taxpayer's ESOP deduction, the taxpayer challenged the constitutionality of the nomi-

117. See Omnibus Budget Reconciliation Act of 1987, Pub. L. No. 100-203, § 10411(a), 101 Stat. 1330, 1330-432 (repealed 1989).

118. See Omnibus Budget Reconciliation Act of 1987, Pub. L. No. 100-203, § 10411(b), 101 Stat. 1330 (repealed 1989).

119. I.R.S. Notice 87-13, 1987-1 C.B. $432,442$.

120. 114 S. Ct. 2018 (1994).

121. The purchase and sale of the stock produced a loss, before taxes, of $\$ 631,000$. However, applying the ESOP estate-tax deduction, the sale generated tax savings of $\$ 2,501,161$. See 114 S. Ct. at 2021. 
nally retroactive effective date, arguing that such retroactivity violates the Due Process Clause. 122

In accordance with a long line of prior cases upholding the constitutionality of nominally retroactive tax-law changes, ${ }^{123}$ the Court rejected the taxpayer's arguments and upheld Congress's retroactive amendment of the ESOP deduction against the due process challenge. Interestingly, in reaching this conclusion, the Court was persuaded by the same factors that made this particular tax transition an appropriate occasion for nominal retroactivity: First, Congress clearly was acting to correct an obvious mistake and was not opportunistically repealing an incentive subsidy. ${ }^{124}$ Second, Congress repealed the provision not long after its original enactment; therefore, the retroactive reach of the statute was short. In fact, the proposal to amend the provision was made only five months after the provision was enacted, and the amendment was enacted less than one year later. ${ }^{125}$

\section{B. Broad-Based Tax Transitions}

Parts II and III concluded that, with respect to the repeal of an incentive-subsidy provision, the optimal ransition policy would entail full ransition relief. This section addresses what I refer to as broad-based tax transitions, that is, transitions that affect a relatively broad group of taxpayers and that have a relatively small defaultpremium effect. The two specific broad-based tax transitions that I discuss are: (a) an increase in federal income tax rates and (b) the

122. See 114 S. Ct. at 2020.

123. See infra note 131 (discussing retroactive-tax cases).

124.

Congress acted to correct what it reasonably viewed as a mistake in the original 1986 provision that would have created a significant and unanticipated revenue loss. There is no plausible contention that Congress acted with an improper motive, as by targeting estate representatives such as Carlton after deliberately inducing them to engage in ESOP transactions.

Carlton, 114 S. Ct. at 2023.

In her concurring opinion, Justice O'Connor criticizes the majority opinion for relying on the argument that the amendment clearly was intended to correct a legislative "mistake." She rightly observes that, at some level, "[e]very law touching on an area in which Congress has previously legislated can be said to serve the legislative purpose of fixing a perceived problem with the prior state of affairs." 114 S. Ct. at 2025 (O’Connor, J., concurring). This argument seems to deny the difference between the repeal of an intended incentive subsidy and the repeal of a provision that has entirely unintended and unexpected incentive effects on taxpayers. Obviously, I think there is a difference. Moreover, it may be that the Court's jurisprudence on retroactive taxation would recognize such a difference as well. The majority's opinion at least suggests that the nominally retroactive repeal of an explicit incentive provision would have a greater chance of violating the due-process standard in this context. See 114 S. Ct. at 2023.

125. See 114 S. Ct. at 2023. 
shift from an income-based tax to a consumption-based tax. For reasons that are discussed below, these two transitions present a type of transition problem that is different from the one presented by the repeal of an incentive subsidy. Hence the optimal transition policy also may be different.

\section{Income Tax Rate Changes}

When Congress changes the federal tax rates, it sometimes makes the rate changes nominally prospective, that is, applicable only to income earned after the date of enactment or after December 31st of the year of enactment. Sometimes, however, it applies the rate changes nominally retroactively, a practice that in recent years has led to a fair amount of controversy. For example, as part of the Revenue Reconciliation Act of 1993 (RRA), ${ }^{126}$ signed into law on August 10th of that year, Congress increased the federal income tax rates of the highest-eaming individuals and corporations. ${ }^{127}$ Although the enactment of the rate increase itself did not get much attention, the effective date that Congress selected ignited a firestorm of controversy. The new 1993 tax rates were made retroactive to the beginning of the year and thus applied to income earned before the new rates were enacted and even before the new administration had taken office. ${ }^{128}$ Taxpayers and some lawmakers expressed shock and dismay at this use of nominal retroactivity. ${ }^{129}$

Although the use of a retroactive effective date in this context is almost certainly constitutional, ${ }^{130}$ some critics in the popular press

126. Pub. L. No. 103-66, § 13001, 107 Stat. 416 (codified at I.R.C. $\S 1$ (1996)).

127. Pub. L. No. 103-66, § 13201(a), 107 Stat. 312 (codified at I.R.C. § 1 (1996)). Before the RRA, the top marginal rate, after all "phase outs" and "bubble" effects, had been $31 \%$. The RRA in effect added two new marginal rates for individuals: $36 \%$ (applied to income between $\$ 140,000$ and $\$ 250,000$ for married couples filing jointly) and 39.6\% (applied to income over $\$ 250,000$ for married couples filing jointly). See I.R.C. \& 1(a) (1996). The new $36 \%$ and $39.6 \%$ rates have been adjusted for inflation for taxable years since 1994 . The RRA also added a new top bracket for corporations: $35 \%$ for income over $\$ 10$ million. See I.R.C. § 11(b)(1)(D) (1996).

128. See Revenue Reconciliation Act of 1993, Pub. L. No. 103-66, § 13201(c), 107 Stat. 416, 459 (codified at I.R.C. § 1 (1996)).

129. See, e.g., 139 CONG. REC. H6392 (daily ed. Sept. 8, 1993) (statement of Rep. Ramstad) ("Mr. Speaker, we have all heard the axiom, "At least we are safe as long as the legislature isn't in session.' But it turns out that the American people are never safe. With passage of the last tax bill, Congress rolled back the clock to a time it was not even in session, to raise taxes retroactively. For the first time in American history taxes were raised retroactive to a previous administration."); Repeal Retroactivity, WALl ST. J., Aug. 10, 1993, at A14.

130. The Supreme Court repeatedly has upheld retroactive tax legislation against constitutional challenges. See, e.g., United States v. Hemme, 476 U.S. 558 (1986); United States v. Darusmont, 449 U.S. 292 (1981); Welch v. Henry, 305 U.S. 134 (1938); United States v. Hudson, 299 U.S. 498 (1937); Milliken v. United States, 283 U.S. 15 (1931). According to the Supreme Court's most recent pronouncement on retroactive federal income taxation, to sur- 
nevertheless questioned the constitutionality of such a practice. ${ }^{131}$ Moreover, retroactive taxation generally elicits a strong negative reaction from most taxpayers. ${ }^{132}$ Despite the controversy, however, the retroactive rate increase in 1993 was not without precedent. The Revenue Act of 1938, which was enacted on May 28, 1938 and which raised the top individual income tax rate from fifty-five to seventy-five percent, was made applicable to tax years beginning after December 31, 1938. ${ }^{133}$ Likewise, the Revenue Act of 1944, passed on May 29, 1944, which raised the top individual rate from seventy-five to ninety-one percent and which substantially reduced the income threshold subject to the top rate, was applied retroactively to the beginning of $1944 .{ }^{134}$

Whether a tax-rate increase is applied nominally prospectively or nominally retroactively, however, some taxpayers will suffer losses in the value of investments made in reliance on the old rates. Thus these questions arise: What is the optimal transition policy with respect to such losses? Should transition relief be provided? If so, in what form? Unlike the incentive-subsidy context, where a strong case can be made for always providing grandfathered effec-

vive a due process challenge Congress's decision to apply a tax change retroactively need only pass the "rational-basis" test. See United States v. Carlton, 114 S. Ct. 2018 (1994); see also infra section IV.B.1 (describing earlier retroactive rate increases).

131. See, e.g., Stephen C. Glazier, Tax Bill: Retroactive, Unconstitutional ..., WALL ST. J., Aug. 5, 1993, at A12 (asserting that a retroactive rate change was unconstitutional).

132. See Levmore, supra note 13 , at 265 ("[R]etroactive taxation ... is generally regarded as abhorrent, unwise, and even illegal."). We are unlikely to see any additional retroactive rate increases from Congress in the near future. In January 1995, the House of Representatives adopted a change to its rules that prevents consideration of a "bill, joint resolution, amendment, or conference report carrying a retroactive Federal income tax rate increase." H. Res. 6, 104th Cong., 1st Sess. § 106(b) (1995). Before the adoption of that new House rule, a number of proposals were introduced that similarly would have limited Congress's ability to change tax provisions retroactively. See, e.g., H.R. 3024, 103d Cong., 1st Sess. (1993) (proposing the elimination of the retroactive tax increases in the RRA); H.R.J. Res. 258, 103d Cong., 1st Sess. (1993) (proposing an amendment to the Constitution outlawing retroactive tax increases); H.R.J. Res. 256, 103d Cong., 1st Sess. (1993) (proposing an amendment to the Constitution to prohibit federal laws from imposing liability for conduct arising before enactment date); H.R. Res. 247, 103d Cong., 1st Sess. (1993) (establishing a point of order under House rules against consideration of measures that contain retroactive tax increases). The relevant language of Resolution 258 reads as follows:

Section 1 . In the case of any provision of law which modifies the tax laws of the United States and which results in increased revenues to the United States -

(1) no such modification of any income tax shall apply to any taxable year beginning

before the date of the enactment of such modification, and

(2) no such modification of any excise tax shall apply to any event occurring before

the date of the enactment of such modification.

H.R.J. Res. 258, 103d Cong., 1st Sess. 2 (1993). 1939).

133. See Revenue Act of 1938, Pub. L. No. 75-554, 52 Stat. 447 (superceded by I.R.C.

134. See Individual Income Tax Act of 1944, Pub. L. No. 78-315, 58 Stat. 231 (superceded by I.R.C. 1954). These rates do not include the small surtax on "normal income." 
tive dates, the optimal policy in the context of a broad-based rate increase is less clear and seems to turn on a slightly different mix of issues.

On a practical level, the use of grandfathered effective dates for a broad-based rate increase is probably out of the question, for several reasons. First, identifying all of the individual investments that were made in reliance on the old tax rates and that would therefore be entitled to grandfather treatment would be impossible. Second, providing grandfather treatment to everyone who made any type of investment before the rate change (whether their decision was influenced by expected tax rates or not) would amount to a policy forbidding any changes in income tax rates. It is hard to imagine that such a policy would be optimal.

On a theoretical level, the very idea of providing transition relief for the losses caused by an income tax rate increase is problematic. When Congress adopts a given rate structure, it generally has two principal purposes in mind: (a) to raise enough money to fund the level of government services that taxpayers want (whether those services be public goods or transfer payments) and (b) to allocate the cost of those services across taxpayers in a way that is considered fair. Thus, when Congress changes the rate structure, it has determined either that a different level of revenue is needed or that a different allocation of the tax burden is appropriate or both. As a consequence, to provide wansition relief for the transition losses caused by a rate increase would directly contradict Congress's prior determination regarding the necessary level of revenue and the appropriate distribution of the tax burden. ${ }^{135}$

For the reasons just described, the use of grandfathered effective dates in the context of broad-based rate increases would almost certainly be inefficient. The same would be true of a newly enacted broad-based tax. But that is only the start of the inquiry. The choice of the optimal effective date (nominally retroactive, nominally prospective, phased-in, or delayed) is much less clear. The answer depends upon whether those transition devices are necessary or helpful in implementing Congress's policy decisions regarding the optimal tradeoff between the goals of raising revenue, obtaining the optimal distribution of the tax burden, and avoiding harmful incentive effects. Consider the example of an increase in the top marginal tax rates for individuals. Such a change could

135. Both Graetz and Kaplow make similar observations regarding tax transitions that are motivated by distributional concerns. See Graetz, Retroactivity, supra note 9, at 82; Kaplow, s.pra note 10, at 519. 
have two general purposes: (a) to raise funds to put toward reducing the federal deficit or to spend on some new government service and (b) to allocate this additional cost to relatively high-income individuals. ${ }^{136}$ In addition, this change could also have undesired incidental incentive effects. For example, it could lead some individuals to substitute leisure for work because the after-tax retum from working is reduced by the change. ${ }^{137}$ Not only in choosing the size and the structure of the rate increase itself, but also, in deciding whether to use nominally prospective, phased-in, or delayed effective dates, Congress will have to balance all of these effects to achieve the optimal result.

\section{Nominally Retroactive Rate Increases: Bolts From the Blue}

So when, if ever, would it be efficient for Congress to apply a tax-rate increase nominally retroactively? A retroactive rate increase could be efficient if it comes as a surprise to taxpayers. In fact, to the extent taxpayers do not anticipate the retroactive effective date, a nominally retroactive rate increase will produce greater allocative efficiency than a nominally prospective rate increase

136. In his 1993 State of the Union Address, President Clinton justified the 1993 rate increase for high-earning individuals and corporations by emphasizing the need to distribute the burden of paying off the deficit fairly across all taxpayers. See Ruth Marcus \& Ann Devroy, Asking Americans to "Face Facts," Clinton Presents Plan to Raise Taxes, Cut Deficit, WASH. Post, Feb. 18, 1993, at A1.

137. Note also that a tax-rate increase can, under certain assumptions, increase rather than decrease taxpayers' work incentives. This would be true if the "income effect" of the rate increase overwhelmed the "substitution effect." See Joseph A. PEchinan, Federal Tax Pourcy 76 (5th ed. 1987).

There is no a priori basis for deciding how the individual income tax affects work incentives. On the one hand, the tax reduces the financial rewards of greater effort and thus tends to discourage work (the substitution effect). On the other hand, it may provide a greater incentive to obtain more income because it reduces the income left for spending (the income effect).

Id. Taking both of these effects into consideration, however, it is quite possible that changes in federal income tax rates have little net effect on taxpayers' work incentive because the decisions whether to work, how much to work, and what career to pursue are influenced primarily by factors other than taxes.

Taxation is only one of many factors affecting work incentives. This makes it extremely difficult to interpret the available statistical evidence or the results of direct interviews with taxpayers. The evidence suggests that income taxation does not greatly reduce the amount of labor supplied by workers and managers who are the primary family eamers. Work habits are not easily changed, and for most people ... there is little opportunity to vary their hours of work or the intensity of their efforts in response to changes in tax rates.

Id. Pechman also notes that "secondary eamers" in a household have greater opportunity to vary their work effort in response to tax-rate changes than do "primary eamers." He concludes, however, that, although the evidence is mixed, "[t]he historical trends in the U.S. labor supply do not... support the view that taxes have had a significant effect on aggregate labor supply." Id. at 77. Some investment decisions other than the work-leisure tradeoff probably are influenced significantly by income tax considerations: for example, whether to invest in taxable or tax-exempt securities. 
would. This is because the retroactive portion of the rate increase will have no distortive effects on taxpayers' incentives. For example, it will not distort taxpayers' choice between work and leisure because it is essentially a surtax on income earned in the past. ${ }^{138}$ Even the cleverest taxpayers cannot change their past actions. Then, given the revenue raised by the retroactive portion of the rate increase, the prospective portion of the rate increase can be commensurately lower than it otherwise would have been. Thus, the distortive effects of the prospective rate increase are reduced. As Professor Levmore puts it, "taxing past transactions means that future behavior may be less distorted by taxes because the rates applicable to the future can be lower than without the retroactive tax."139 On this theory, the 1993 retroactive rate increase may have been more efficient than a nominally prospective rate increase designed to produce the same amount of tax revenue would have been.

The benefits of applying tax-rate increases retroactively, however, should not be overstated. To produce the desired efficiency effects, Congress would have to promise credibly that it would never enact a retroactive rate increase again or at least not for a long time. Without such a credible commitment, taxpayers would alter their behavior in anticipation of future retroactive rate increases, thereby reducing and perhaps eliminating the efficiency benefits of the initial retroactive tax.140 What's more, taxpayers may be less likely to believe Congress's commitment if it comes on the heels of the first surprise retroactive tax. ${ }^{141}$

138. See Levmore, supra note 13 , at 273.

139. Id. Levmore's analysis seems to assume a large one-time retroactive tax that is not attached to a nominally prospective rate increase. See id. at 276 ("a onetime, large-scale (progressive) expropriation of private property").

140. Levmore acknowledges this qualification. See id. at 274,276 . He responds, however, that even if the retroactive tax is only a partial surprise (it surprises only some taxpayers) there still will be some efficiency gains. See id. True enough. However, having been hit once with a "bolt from the blue," $i d$. at 277 , and knowing that Congress will be tempted to try the same trick again, taxpayers will begin to watch the sky for the next one. This is the quintessential example of the time-consistency problem. See Stanley Fischer, Dynamic Inconsistency, Cooperation and the Benevolent Dissembling Government, 2 J. EcoN. DYNAMICS \& CONIROL 93 (1980) (demonstrating the benefits of credible government commitment to optimal tax-policy plan); Kydland \& Prescott, supra note 54. Moreover, given the salience of the first retroactive tax, taxpayers may have a tendency to overestimate the chance of its reoccurrence. To avoid these problems, a credible precommitment device is needed. Perhaps the new House rule, adopted by the House of Representatives following the RRA that prevents consideration of retroactive income tax rate increases, is just such a commitment device. See infra notes $169-70$ and accompanying text.

141. See Kaplow, supra note 10, at 576 ("To a large degree, expectations concerning future government policy will depend on past decisions, so consistent action over time can be quite important in fostering desired expectations."). 
One might expect that the larger the initial retroactive tax is the harder it would be for Congress to convince taxpayers that it would not happen again. At the same time, however, the retroactive tax must be sufficiently large to be worth the trouble. That is, if the retroactive tax were relatively small, the efficiency benefit would likewise be small because a small retro-tax would fund only a small reduction in prospective rates. For example, consider the individual rate increase included in the RRA 1993, which was only 3.6 percentage points. It is difficult to imagine that, by applying that rate increase nominally prospectively, the increase would have needed to be considerably larger to generate the same amount of revenue. If, however, the rate increase were extraordinarily large, there might be efficiency gains to a nominally retroactive effective date. 142 Even then, given the offsetting income and substitution effects, it is unclear whether there would be any efficiency gains.

Moreover, if we take into account the negative public reaction to the nominally retroactive rate increase in 1993, and we consider all the time and resources spent debating the issue and explaining it to an incredulous public, the overall costs of the retroactive effective date probably exceed the benefits. In response to taxpayer and lawmaker complaints about the effective date, some of the revenue that was generated by the retroactive application of the rate increase was given right back to taxpayers via a special transitionrelief provision. Under that provision, individuals whose 1993 income taxes were increased as a result of the rate change could elect to pay the additional tax in three equal installments in 1994, 1995, and 1996.143

\section{The Shift From an Income Tax to a Consumption Tax}

The competing concerns of optimal distribution and optimal incentives must be balanced not only whenever Congress considers raising federal income tax rates but also whenever it considers any sort of broad-based tax transition. Another such transition would be the shift from the current income tax to a broad-based consumption tax. In discussions of the transitional problems that such a shift presents, commentators often consider two general types of transi-

142. For example, the potential efficiency benefits of nominal retroactivity were substantially greater with the large rate increases of 1938 and 1944 than with the relatively small rate increase of 1993. See supra notes 133-34.

143. See Revenue Reconciliation Act of 1993, Pub. L. No. 103-66, § 13201(d), 107 Stat. 416, 459-61 (codified at I.R.C. § 1 (1996)). 
tion effects: "price changes" and "carryover problems."144 The price-change issue is what I have been discussing all along: what to do about the reduction in the value of taxpayers' pretransition investments caused by the loss of preferential tax treatment of those investments. In the shift to a broad-based consumption tax or a socalled flat tax, many incentive subsidies would presumably be repealed. With respect to those transitions, the arguments in Parts II and III regarding the optimal transition policy would apply. Full transition relief should be given to the nominal beneficiaries of the repealed subsidies.

The carryover problem, however, is somewhat different and is best defined by example. The carryover problem that has received the most attention involves the question of how to deal with the following situation: Under an income tax regime, an individual taxpayer accumulates wealth on an after-tax basis, that is, the initial investment was made from after-tax dollars and the earnings on that investment are taxed as accrued. Then, following the switch to a consumption tax, the individual begins to draw on this pretransition wealth to make consumption expenditures. The problem is that, if the taxpayer is given no special transition relief, the taxpayer's post-transition consumption expenditures made with pretransition savings will be taxed again. This amounts to a type of double taxation or tax penalty on those who did most of their saving under the income tax, in the following sense: "The combined income and [consumption] taxes on an individual caught in the transition might be greater than the total taxes which would be imposed if all his income, savings, and consumption had taken place under either an income tax or [a consumption] tax."145

The question therefore is whether to provide transition relief to taxpayers caught in this position. One response would be to treat all pretransition investments as being "tax prepaid" and to exclude those assets from being taken into account in determining taxpayers' consumption tax liability under the new tax system. This would essentially be a form of grandfather treatment. The response at the other end of the spectrum would be to provide no transition relief

144. This terminology was first used by the Treasury Deparment in its discussion of transition issues presented by shifting to a "broadly based tax system," either a broad-based income tax or a broad-based consumption tax. See BLUEPRINIS, supra note 20, at 159-87. The distinction has been used subsequently and to some extent criticized by tax-policy analysts. See Graetz, Consumption Tax, supra note 26, at 1649-59 (acknowledging the distinction but arguing that the two should be treated analytically as one); Kaplow, supra note 10, at 611-14 (arguing that the two phenomena merit different treatment).

145. Graetz, Consumption Tax, supra note 26, at 1653-54. For a general discussion of several different carryover problems, see BLUEPRINI, supra note 20, at 160-61. 
and to treat the pretransition investments as being tax prepaid. This would essentially be a form of nominal prospectivity. The main difference between these two approaches would be the allocation of the relative tax burden across various classes of taxpayers. The grandfathering or tax-prepayment approach would impose a relatively low tax burden on taxpayers who have large accumulations of wealth when the transition occurs and a relatively high tax burden on taxpayers whose primary wealth accumulation takes place after the transition and whose consumption is not funded primarily from pretransition wealth. ${ }^{146}$ The nominally prospective approach would have just the reverse effect. In between these approaches, one could imagine a number of possible compromise solutions, involving phased-in or delayed effective dates. ${ }^{147}$

Whatever proposal is chosen should reflect the government's determination of the appropriate distribution of the tax burden among individual taxpayers. Thus, it is possible that social welfare would be maximized if a transition rule is adopted that results in roughly the same allocation of total tax burden as existed before the shift from an income to a consumption tax. Alternatively, the welfare-maximizing transition rule might increase slightly the tax burden on those taxpayers who have substantial amounts of pretransition wealth and slightly reduce the tax burden of those who have not.

146. The Treasury Department explains these effects as follows: "[I]f owners were allowed to treat those assets as tax-prepaid, they would receive a gain to the extent they planned to use them for future consumption. Future income on past accumulated wealth would then be free from future taxes, and the government would have to make up the difference by raising the tax rate on the remaining consumption regarded as non-pretaxed." BLUEPRINS, supra note 20, at 160 .

147. The Treasury Department proposes a tax-prepaid approach, but it also recommends a 10-year phase-in period during which taxpayers would be required to calculate their income under both the old income tax and under the consumption tax and pay whichever tax liability is greater. Then, at the end of the 10 -year period, all unrealized capital gains would be subject to taxation. See id. at 184-85. Graetz contends that the Treasury proposal would pose undue administrative burdens, and he seems to suggest that the use of a delayed effective date would be a superior alternative. See Graetz, Consumption Tax, supra note 26, at $1655-$ 58. In addition, Graetz suggests that, if the pretransition wealth-accumulation problem must be remedied, a better approach would be "an immediate deduction of the basis of assets held on the date of enactment (perhaps limited to a maximum dollar amount with a carryover or required spread over a period of years)." Id. at 1655. An additional complication is how to deal with those pretransition assets that were purchased with before-tax dollars, for example, accumulations in pension funds whose original contributions and eamings have been excluded from the income tax base. If such investments are likewise treated as tax prepaid, they would be receiving a subsidy rather than a tax penalty upon the shift to a consumption tax. The obvious solution would be to distinguish pretransition assets according to whether they were funded by before-tax or after-tax dollars. But this would increase the complexity of the system considerably. The increase in administrative costs associated with such a system may or may not outweigh the benefits. 
Note also that under the framework of this article the choice of the optimal transition policy for dealing with carryover problems depends more upon distributional issues than incentive issues. This conclusion is based on the intuition that the failure to provide transition relief in this context probably will not produce the same degree of default premiums as an opportunistic incentive-subsidy transition. That being said, however, it must be admitted that the shift from an income tax to a consumption tax, if accompanied by no transition relief whatever, conceivably could have significant incentive effects, simply because of the potential magnitude of the wealth transfer. Taxpayers making future decisions regarding savings and consumption would not soon forget receiving such a hit from the tax collector. In fact, the effect would be similar to that of an extremely large income tax rate increase, one that was large enough to have a significant immediate impact on the distribution of income in society. ${ }^{148}$

\section{IMPLEMENTATION}

This Part addresses several specific issues of design that arise out of the thesis of the article. First, I discuss two practical issues that must be addressed in the design of an efficient grandfather clause. Then I return to the theme of government precommitment, and I outline several possible devices through which Congress might precommit itself to the tax-mansition policy developed in Parts II and IV above.

\section{A. Designing a Grandfathered Effective Date: The Issues of Transferability and "Under-the-Wire" Investments}

Having set forth the basic efficiency argument for guaranteed grandfather treatment for incentive subsidies, now let us consider two specific design questions: whether the grandfather treatment should be transferable and what should be the effective grandfather date. The first problem asks whether grandfather treatment should be applied to any investment made prior to the enactment date of

148. Kaplow recognizes an analytical difference between price changes and carryover problems; he argues that the former should not receive transition relief for incentive reasons, and the latter should receive some type of transition relief for distributional reasons. See Kaplow, supra note 10, at 612-14. The difference in my argument is that I would give the former full transition relief, at least in connection with incentive-subsidy transitions. My analysis of carryover problems and of income tax rate increases also would apply to other broad-based tax transitions: for example, the decision to enact an income tax or consumption tax in the first place or the decision to increase the amount of social-security benefits that is subject to income taxation. 
the new law. I refer to grandfather treatment that attaches to the investment as transferable grandfathering. Alternatively, grandfather treatment could be applied only to taxpayers who hold the assets on the date of enactment or some other specified date, thus denying the benefits of the new law if the asset is transferred to another taxpayer. I refer to grandfather treatment that attaches only to the holder on the date of enactment as nontransferable grandfathering. ${ }^{149}$

An example illustrates the distinction. Assume Congress has decided to repeal the exclusion for interest earned on state and local bonds, but it also decides to provide grandfather treatment for those taxpayers who invested in state and local bonds before the repeal. Thus, Congress inserts a grandfathered effective date that applies the old tax exemption to income earned on any state and local bonds purchased before the date on which the repeal was first proposed. If this effective date were made nontransferable, the old tax exemption would be available only to those taxpayers who held a qualifying tax-exempt bond when the repeal was first proposed. Accordingly, if the taxpayer were to sell the bond under this rule, the new owner would not get the benefit of the grandfather clause but would be taxed on the income she received from the bond. On the other hand, if the effective date were made transferable, the grandfather treatment would follow the bond to the new owner. Hence, interest earned on the bond would be exempt no matter who held the bond for as long as the bond generated interest.

Some commentators have argued that transferable grandfather treatment is inappropriate because it results in a windfall to taxpayers who owned the tax-favored assets at the time of the transition. ${ }^{150}$ This gain occurs because the value of the grandfathered asset increases relative to the value of other assets of the same type that happen to be purchased after the transition and thus do not get the benefit of the old incentive subsidy. In the example above, the state and local bonds that enjoy the transferable grandfather treatment would, after repeal of the tax exemption, increase in value relative to those state and local bonds that did not get grandfather treatment. The holder of the grandfathered bonds could sell them at a premium. The alternative, however, of using nontransferable grandfathering could result in a transition loss to the taxpayers

149. See BlUEPRINT, supra note 20 , at 167 ; Graetz, Retroactivity, supra note 9 , at 53,60 63. Graetz refers to nontransferable grandfather clauses as "holder-only grandfathered effective dates." Id. at 53.

150. See Blueprints, supra note 20 , at 167. 
holding the' assets at the time of transition. Under such a rule, the taxpayer who owned a tax-exempt bond when the repeal was announced would continue to enjoy the tax exemption only so long as she continued to hold the bond. If, however, she wanted to sell the bond, its market value would have fallen relative to the value before the repeal because any purchaser of the bond would be subject to a tax on the bond's interest eamings.

Under the theory of this article, Congress should decide whether the grandfathered effective dates used in connection with incentive-subsidy transitions should be made transferable or nontransferable. The type of analysis that Congress should use in making this decision is akin to the analysis that a product manufacturer would make in deciding whether to make a warranty transferable or nontransferable. If a product manufacturer, for example, were to insert a warranty with its product that guaranteed certain parts for the life of the product or for as long as the original purchaser owns the product, the warranty would be in effect nontransferable. The reason a manufacturer would opt for such a warranty, obviously, is that the manufacturer would have to pay out fewer claims under its warranties. In addition, a nontransferable warranty may be less costly to administer. At the same time, the manufacturer would hope not to lose so many sales owing to the cheaper, nontransferable warranty that the costs of making it nontransferable exceed the benefits. The alternative (a transferable warranty) would require more claim payments by the manufacturer but, on net, might produce greater profits because consumers really may want a transferable warranty.

Congress should go through the same cost-benefit analysis when deciding whether to make its guarantee of grandfathered effective dates transferable or not, and it should announce its decision publicly upon the original enactment of the incentive-subsidy provision. This could be done either in the statute itself or in the Joint Committee report that is published following the enactment of federal income tax legislation. If Congress chooses a transferable effective date, it then might be able to reduce the amount of the initial incentive subsidy; for example, instead of a $100 \%$ exemption for state and local bond interest, it could provide a $90 \%$ or $80 \%$ exemption and still induce the desired level of investment in state and local bonds. It is still possible, of course, that a nontransferable effective date would be the optimal approach. That might be true, for example, of incentive-subsidy provisions that are paid to taxpayers over long periods of time. In addition, it might be that a transferable 
effective date would be unduly costly to administer. ${ }^{151}$ In any event, clearly the wrong approach (in the interest of reducing default premiums and maintaining the integrity of the taxing authority) would be for Congress to give the impression that it would provide transferable grandfathering only to change its mind at the time of the transition and apply a nontransferable effective date. That would be government opportunism.

If a grandfathered effective date is to be used, what date should be chosen: the date of enactment or some earlier date? If the date of enactment is to be used and if taxpayers know this, there suddenly will be an enormous incentive (once the transition is being considered by Congress but before it has been enacted) for taxpayers to increase their level of investment in the asset that is going to lose the preferential tax treatment. This is sometimes called "under-the-wire" investment activity, and it can be viewed as a form of taxpayer opportunism that the optimal transition policy would discourage. With an ideal transition policy, under-the-wire investments (those investments that would not have occurred but for the imminent repeal of the incentive subsidy) would not receive grandfather treatment. ${ }^{152}$ At the same time, however, grandfather treatment should be given to whatever investments were made in reliance on the incentive subsidy's existence, so long as that investment was made prior to the repeal of the subsidy. ${ }^{153}$ One possibil-

\section{See Goldberg, supra note 12 , at 322 \& n. 42 .}

152. Under-the-wire investments can also be seen in other transition contexts. For example, when word gets out that a state govemment is planning to exercise its power of eminent domain to condemn all of the property in a given area for the purpose of building a road, landowners in the targeted area may have an increased incentive to build structures on their property because of the prospect of increasing the price the govemment must pay for their property. This is a form of moral hazard, and the optimal transition rule would discourage such investments.

Kaplow suggests that there is no analytical difference between what I call under-the-wire investing in a tax-favored asset and any other pretransition investment in such an asset. He argues that they differ only in degree and thus that neither type of investment should receive grandfather treatment. See Kaplow, supra note 10, at 608 . I think there is an analytical difference, which is revealed in the contract analogy. If the government were to enter into a contract with a private developer under which the developer was to construct low-income housing units, the contract would include specific terms setting forth what is expected of both sides, including how many units the govemment was willing to pay for, a number that the government presumably determined to be the optimal amount. If the government later determined that it no longer wanted to buy government housing from this developer, it would have to comply with the current contract, but it could decline to enter into future contracts with the developer. This is comparable to a transition rule guaranteeing grandfathered effective dates for incentive-subsidy transitions. Providing grandfather treatment for under-thewire investments in the context of an incentive-subsidy transition, on the other hand, would be akin to allowing the developer in the contract example to force the government to reimburse it for housing units that were not part of the original contract.

153. In section III.C supra, I discuss why the enactment date is the appropriate cutoff point. 
ity would be for Congress to try to sort out these two types of investments and grandfather the latter but not the former. To do so with perfect accuracy, however, would be impossible. So we are left to choose among imperfect alternatives.

Under one approach, grandfather treatment would be provided to any investments made before the date on which the repeal of the subsidy was first proposed in Congress. ${ }^{154}$ Any investment made before that date would get grandfather treatment; any made afterward would not. One benefit of that rule would be its administrability; it would provide a bright-line test that could readily be applied. The problem with the rule, however, is that it is both overinclusive and underinclusive. The rule is overinclusive because some taxpayers receiving grandfather treatment would have engaged already in a substantial amount of under-the-wire investing before that date. Some taxpayers, in other words, will inevitably learn of the transition proposal before it is formally announced in Congress and will simply make their under-the-wire investments a little earlier to circumvent the rule. ${ }^{155}$ The rule is underinclusive because some taxpayers who will be denied grandfather treatment (that is, some of those who make investments after the announcement date) will not be engaging in under-the-wire investing at all. Those taxpayers' post-announcement investments are not motivated by the imminent repeal of the subsidy. Of course, some amount of over- and underinclusiveness is inevitable. And using the date on which the proposal was first proposed in Congress seems better than any of the other alternatives. A later date would probably encourage too much under-the-wire investing, and an earlier date would probably be too difficult to administer. ${ }^{156}$

154. See Kaplow, supra note 10, at 607-08 \& nn.305-06.

155. One would not be surprised if these taxpayers had expensive tax counsel.

156. If the overinclusiveness problem were thought to be serious, exceptions could be made in certain cases of egregious abuse. For example, if it could be demonstrated that some taxpayer suddenly increased her investment in some tax-favored asset by an enormous amount the week before a proposal to repeal the tax preference is introduced in Congress, grandfather treatment could be denied. Likewise, with the underinclusiveness problem, exceptions could be made if taxpayers could prove that their post-announcement investments would have been made anyway. Both of these exceptions, however, add complexity and cost to the system.

It is also worth observing that, when an incentive-subsidy provision is enacted, there is of ten a compelling reason to make the provision nominally retroactive to the date on which the provision was first proposed. If Congress announces that it is considering enacting a particular incentive-subsidy provision, and it announces that the provision will be applied nominally prospectively if enacted, there will be a large and inefficient lull (perhaps even a total stop) in the type of investment that the subsidy is intended to encourage. This lull will begin on the date the proposal is announced and will end on the effective date of its enactment, as taxpayers who have been waiting to get the benefit of the subsidy suddenly rush to make the investment. Because the period between when a subsidy is first proposed and 


\section{B. Congressional Precommitment Devices}

Once we have identified the optimal ransition policy for tax transitions, the next challenge is to develop a mechanism by which the government can credibly commit itself to this policy. Without an effective precommitment device, the incentive effects of any transition policy disappear.157 As an initial matter, however, one might reasonably question the need for a government precommitment device, on the theory that the democratic political process and electoral accountability should be sufficient to ensure that the government will always apply the optimal transition policy. For example, if Congress were to deliberate over whether to repeal the lowincome-housing credit and whether to provide grandfather protection for those who had invested in reliance on the credit, those taxpayers who had relied on the credit would have an incentive to lobby the tax-writing committees to insert such a transition rule. In addition to the effects of private lobbying, the overall effect of alternative transition policies on the government's reputation and integrity may help to keep lawmakers in line. After all, at some later date (or perhaps even in the same session of Congress) those lawmakers may want to enact a new incentive subsidy to replace the old one; they therefore want to minimize the default premium. For all of these reasons, members of Congress have a strong incentive to avoid even the appearance of opportunistic behavior.

So where's the problem? As I suggested in Part II, there may not be a problem. It is conceivable that, for the reasons just described, lawmakers already have adequate incentives not to act opportunistically and instead have incentives to choose the optimal effective date for every type of tax ransition. In other words, it is entirely possible that the assumption in Part II of congressional myopia is unfounded. If so, if Congress already is pursuing the optimal transition policy with respect to tax transitions, then this article serves to clarify and make explicit the justification for that practice and to suggest reasons why that transition policy should be solidified and publicized.

when it is enacted and made effective sometimes can be quite long, Congress will of ten make the subsidy retroactive to the date on which it was first proposed; that transition rule will be announced from the very beginning, so that taxpayers will not have an incentive to wait for enactment before making the investment.

157. See generally Shepsle, supra note 2, at 246-47, 250-57 (discussing, in general terms, the efficiency benefits of, and outlining several approaches to, "disabling" the government's discretionary policymaking authority). Kaplow notes that there are incentive benefits to the government's credibly precommitting to an optimal transition policy; however, he argues that the optimal transition policy generally is not to provide transition relief. See Kaplow, supra note 10 , at 576 . 
It may be the case, however, that there is a problem or at least the potential for one. First, it has been suggested that, in choosing effective dates for tax transitions, Congress follows "no discernible principle" or pattern. ${ }^{158}$ If that is true, then Congress is not following any single coherent transition policy but is instead making transition decisions on an ad hoc basis. Second, as discussed in Part II, it is probably safe to say that lawmakers are like the rest of us and sometimes fail fully to consider the long-run effects of their decisions on the integrity of the government. ${ }^{159}$ Certainly, lawmakers will be tempted from time to time to act opportunistically, perhaps when the need for additional revenue is especially acute (for example, during a movement for tax reform or deficit reduction) or when the public's attention is not focused on the decision or when, for whatever reason, the party that stands to suffer the transition loss lacks political clout. Therefore, one of the principal aims of this article is to emphasize the need for lawmakers in all of these situations to take into account the full costs associated with failing to provide adequate ransition relief. Moreover, because of the possibility of this sort of temptation, it is worth considering additional ways in which we might limit the government's ability to give in to it. ${ }^{160}$ Indeed, just such a concern, which persists despite the constraints imposed by the normal political process, explains our decision to make the government subject to contract-law principles.

That being said, let us now consider a number of devices that might be used to raise the cost to Congress of changing its mind regarding what transition rule to apply to a given tax transition. Some of these devices may currently be in use or may have been tried in the past, although they may not have been understood in these terms. Others have not yet been tried and should be. For purposes of this article, we shall concentrate on commitment devices that might be used by Congress in connection with changes to incentive-subsidy provisions in the Internal Revenue Code as well as some other types of tax transitions. It bears reemphasizing, however, that versions of these devices could be used just as readily by other levels of government in connection with other types of legal transitions.

158. See Graetz, Retroactivity, supra note 9, at 48.

159. See Kydland \& Prescott, supra note 54, at 474.

160. But see Kirk J. Stark, The Elusive Transition to a Tax Transition Policy and the Role for a Grandfather Rules Budget, AM. J. TAX PoLy. (forthcoming 1996) (arguing that congressional precommitment is unlikely to work, given the history of frequent tax-law changes and given structural changes in congressional committees which allow more input by more diverse parties than previously). 


\section{Contract Law: Lessons From the Winstar Case}

Contract law could provide a way to force the government to shoulder the costs of opportunistic tax transitions. One could allow taxpayers harmed by the repeal or elimination of an incentive subsidy to sue for damages under a breach-of-contract theory. The appropriate remedy would presumably be expectation damages or some approximation thereof, which could be calculated by determining what the relying party's return would have been had the incentive subsidy not been repealed or, alternatively, had the subsidy been repealed but grandfathered. Making such damage calculations would be no simple task. But it would be no more difficult than making damage calculations in other contract disputes. In addition, as I.suggested in section III.C above, the difficulties inherent in determining who would be entitled to recover in the event of a repealed subsidy would be no greater than the difficulties inherent in determining who is entitled to recover in any complex contractual dispute.

A recent decision by the Federal Circuit provides some insight into how contract law can be used to hold Congress and its agents to their commitments. In Winstar Corp. v. United States, ${ }^{161}$ the Federal Circuit, upholding the Court of Claims, essentially found that Congress, through the Federal Home Loan Bank Board (FHLBB) and the Federal Savings and Loan Insurance Corporation (FSLIC), had entered into contracts with a number of savings-and-loan institutions ("thrifts") and that Congress had broken those contracts. What is interesting for current purposes is that the nature of the events that gave rise to those contracts were not terribly different from the circumstances surrounding the use of any incentive subsidy.

In the late 1970s and early 1980s, interest rates were extremely high and many thrifts were on the brink of insolvency, in part because of long-term fixed-loan obligations entered into during periods of relatively low interest rates. As a result, instead of enacting a direct subsidy payment to the failing thrifts or taking them over and running them directly, the FHLBB and FSLIC offered special regulatory-accounting treatment to any healthy thrift that would merge with a failing thrift. The special accounting treatment effectively allowed those thrifts that responded to the inducement to treat certain assets of the ailing thrift (the so-called supervisory goodwill) as regulatory capital, thereby making it easier for the ac- 
quiring thrifts to satisfy regulatory solvency requirements. I call this the "Winstar subsidy." A number of healthy thrifts responded to the inducement: They applied to the FHLBB for approval of their plans to merge with ailing thrifts; after a series of negotiations, the Bank Board approved the plans, and the mergers took place.

In 1989, however, Congress enacted the Financial Institutions Reform, Recovery, and Enforcement Act of 1989 (FIRREA), ${ }^{162}$ which included, among many other things, a provision that essentially eliminated the Winstar subsidy. Furthermore, and what is most important for the purposes of this article, Congress in the FIRREA provided no transition relief for those thrifts that had relied upon the subsidy. Therefore, as a result of the FIRREA, many thrifts were thrown into noncompliance with regulatory-solvency requirements. Some of the thrifts so harmed, including the Winstar Corporation, sued the United States in the Court of Claims, alleging that the provision in the FIRREA which eliminated the Winstar subsidy amounted to a breach of contract. The Court of Claims held for the thrifts, and the Federal Circuit agreed.

The holding in these cases is consistent with the framework of this article. Had the courts reached the opposite conclusion and had the government been permitted to renege on its deals with the thrifts, there probably would have been serious consequences for the future use of incentive subsidies. Any future attempt by Congress or its agents to use accounting subsidies to induce financial institutions to change their investment decisions would require a substantial default premium. Moreover, if the courts had held in favor of the government, commercial parties in many contexts (not just thrifts faced with favorable accounting rules) would suddenly become more suspicious of government promises of future benefits and likely would demand a substantial default premium before acting in reliance on government inducements. ${ }^{163}$

162. Financial Institutions Reform, Recovery, and Enforcement Act of 1989 (FIRREA), Pub. L. No. 101-73, 103 Stat. 183 (codified in relevant part at 12 U.S.C. § 1464 (1994)).

163. One commentator has argued that the Winstar court's reasoning was deeply flawed because it failed to recognize that the original incentive subsidy (the special accounting treatment promised for healthy thrifts that merged with ailing ones) was a mistake from the start and that Congress, in passing the FIRREA, "was right to negate these deals." Jonathan R. Macey, Rule of Law: The Court Gets It Half Right on Firrea, WALL St. J., Sept. 13, 1995, at A13. It is unclear whether the author would apply the same reasoning to government contracts. If so, the analysis would seem to suggest that the government should have the right to annul any government contract that it determines ex post to have been ill-advised, without having to pay damages. In addition, the author at times seems to suggest that government "bureaucrats" should not have been in charge of detennining which thrifts received the favorable accounting treatment: "Congress [when enacting FIRREA] should have gone much further and relieved all federal bureaucrats of the power to cut special deals with particular favored constituents." Id. But that argument proves too much; under similar reason- 
The holding in Winstar, of course, does not imply that contract law should necessarily apply to the repeal of a generic incentive subsidy, such as an incentive tax credit. There are potentially important differences between the subsidy in the Winstar case and a tax credit. For starters, in the Winstar situation, each applicant for the accounting subsidy was required to negotiate the deal with the government via the Bank Board in advance of any merger. Thus, the subsidy was structured very much like a traditional government contract. The enactment of a tax credit, however, does not necessarily require negotiation on a taxpayer-by-taxpayer basis.

Fair enough. Neither the magnitude nor the relevance of this difference should be overstated, however. First, many business taxpayers do, in effect, seek preapproval of some types of tax subsidies. This can be seen, for example, in taxpayers' requests for private-letter rulings from the Internal Revenue Service (IRS), rulings that are often considered necessary by taxpayers before they will enter into certain tax-favored transactions. Likewise, with respect to some incentive tax subsidies, the Treasury Department promulgates detailed regulations setting forth specific requirements that must be met by any taxpayer who seeks the benefit of the subsidy. Given these facts, the difference between the incentive tax subsidy and the Winstar subsidy seem less obvious.

Consider the following scenario: Congress enacts an incentive subsidy in the form of a tax credit; the Treasury Department issues regulations detailing the requirements that a taxpayer must satisfy in order to receive the credit; and the IRS issues numerous rulings explaining how the credit will apply in many different specific factual situations. Unsurprisingly, some taxpayers act in reliance on the regulations and rulings and make some investments expecting to receive the credit. If, at that point, Congress were to repeal the credit without providing grandfather treatment, the resulting transition losses would be quite similar to the damages suffered by the plaintiffs in Winstar.

Even if, however, one is persuaded that the economics of the Winstar subsidy are not substantially different from the economics of other incentive subsidies, to apply the holding of Winstar to the repeal of an incentive tax subsidy might require a change in the Supreme Court's jurisprudence in this area. Under the "unmis- 
takability doctrine," as it has been applied, the enactment of an incentive subsidy may not be considered an action by Congress expressly intended to bind future congresses. ${ }^{164}$ What if, however, upon enacting an incentive tax credit, Congress were to insert language of the following sort: Any taxpayer who acts in reliance on this incentive credit and who claims the credit on her federal income tax return will have a contractual right to that credit so long as the credit is in force and has not been repealed as of the time the investment is made; this right will be enforceable against the U.S. government. Arguably, such a contract would be enforceable. ${ }^{165}$

\section{Formal and Informal Procedural Changes in Congress}

If one rejects the use of contract law as a congressional precommitment device in this context, there are other potential means of binding Congress to keep its commitments. Congress could institute formal or informal procedures that would impose roadblocks to changing the tax laws in ways that are inconsistent with the optimal ransition policy. In the context of incentive-subsidy transitions, Congress could adopt formal or informal rules that prevent the enactment of legislation that would repeal or substantially reduce any existing incentive subsidies unless grandfathered effective dates were also provided. The one exception to this rule would be any change in tax provisions that can easily be defended as a measure designed to correct an obvious error of the sort described in section IV.A above. Such a transition policy could be implemented through a change in the House or Senate rules. For example, the following rule could be adopted:

Any legislation that would repeal or cut back an incentive subsidy must include a grandfathered effective date. If, however, it is demonstrated that the legislation is necessary to correct an obviously erroneous taxpayer interpretation of the prior law, and if the legislation designed to make this correction is submitted to Congress within one year of the enactment of the prior law, no grandfathering is necessary. Furthermore, in situations involving corrections of obvious errors of this sort, the effective date will be made nominally retroactive to the date of enactment of the original provision. ${ }^{166}$

164. See Bowen v. Public Agencies Opposed to Social Sec. Entrapment, 477 U.S. 41, 5154 (1986); see also Winstar, 64 F.3d at 1546-47.

165. Under the Winstar holding, if Congress were then to repeal the incentive tax credit without providing transition relief, arguably the U.S. government could be sued in contract. Moreover, consistent with Winstar, legislation repealing such a credit would not be exempted from contract principles by the "sovereign-acts" doctrine. See Winstar, 64 F.3d at 1548-50.

166. If this rule seems too strict, it could be changed as follows: If legislation repealing or cutting back an incentive-subsidy provision does not include a grandfathered effective date and does not satisfy the "error-correction" exception, it must be passed by a three-fifths vote 
This formulation presents some obvious difficulties, which I discussed in section IV.A above. The benefits of such a provision may, however, be more than offsetting.

The House of Representatives recently adopted a rule that is similar to the one suggested above but that is directed at income tax rate increases. The rule prevents consideration of a "bill, joint resolution, [or] amendment . . . carrying a retroactive Federal income tax rate increase."167 As suggested in the previous Part, this rule could indeed be efficient, as it gives taxpayers some measure of assurance that Congress will not do again what it did in 1993; namely, enact a nominally retroactive rate increase. The House also adopted another rule change, one that requires a three-fifths vote rather than the normal majority vote to enact a tax increase. The new rule provides, specifically, as follows: "No bill, joint resolution, amendment, or conference report carrying an income tax rate increase could be considered as passed or agreed to unless so determined by a vote of not less than three-fifths of the members voting."168 This provision has provoked considerable criticism from legal academics, primarily from scholars of constitutional law. ${ }^{169}$ The principal criticism is that the change in the House rules is inconsistent with the text, structure, and history of the Constitution and inconsistent with past congressional practice. I leave those issues for now to the constitutional scholars and congressional historians. ${ }^{170}$ Instead, I want to emphasize the potential efficiency benefit of the new House rule, a benefit derived from the effect of the rule on taxpayers' expectations about future changes in federal income tax rates. Although, as I suggested in section IV.B.1, most income tax rate increases probably do not significantly distort work incentives, they do distort them some. To the extent the new House rule reduces the likelihood of rate increases or at least reduces the likelihood of extremely large rate increases, these distortions are

rather than a nomal majority of lawmakers. Also, Congress could create a list of Code provisions that qualify as "tax subsidies," much as it has done with tax expenditures. The former list would likely be shorter than the latter because it would include only those taxexpenditure provisions that are designed for their incentive effect (that is, for their effect on taxpayers' investment decisions) and not those that are primarily redistributive in nature.

167. H.R. Res. 6, 104th Cong., 1st Sess. § 106 (1995).

168. H.R. Res. 6, 104th Cong., 1st Sess. § 106 (1995).

169. See Comment, An Open Letter to Congressman Gingrich, 104 Y ALE L.J. 1539 (1995) (calling for reconsideration of the resolution regarding three-fifths-vote requirement) (signed by 17 law professors).

170. See also John O. McGinnis and Michael B. Rappaport, The Constitutionality of Legislative Supermajority Requirements: A Defense, 105 Y ALE L.J. 483 (1995) (defending the constitutionality of the three-fifths-vote requirement). 
mitigated, and allocative efficiency is enhanced. In addition, the new rule will reduce the number of rate changes over time, which will reduce the administrative costs associated with frequent Code revisions, not the least of which are fees paid to attorneys and accountants. ${ }^{171}$

If, for whatever reason, formal procedural rules are shunned, a similar precommitment function could be served by the congressional tax-writing committees. Thus, for example, the House Committee on Ways and Means and the Senate Finance Committee could serve the function of strengthening and enforcing the institutional presumption in favor of grandfathering significant changes to incentive-subsidy provisions. ${ }^{172}$ If those committees were to adopt an informal practice of requiring grandfather clauses to be attached to all amendments to incentive-subsidy provisions, with the exception of corrective legislation mentioned above, and if this practice were made known to taxpayers, default premiums could be reduced significantly. ${ }^{173}$

\section{Allocating Authority to the Treasury Department and the IRS}

The allocation of decisionmaking authority by Congress to administrative agencies can be seen as an important type of precommitment technique. When Congress delegates authority to an agency, it does so for two general reasons: (a) to put a particular type of decision in the hands of experts who have the training and the time to do the job properly and (b) to give the decisionmaking authority to individuals who are relatively free from the influences

171. Another example of a procedural rule designed to limit Congress's legislative discretion is the Gramm-Rudman Act. See generally Kate Stith, Rewriting the Fiscal Constitution: The Case of Gramm-Rudman-Hollings, 76 CAL. L. REv. 593 (1988). Of course, the ultimate rule of this sort would be a constitutional amendment requiring Congress to provide transition relief in these contexts. See, e.g., supra note 132 (citing proposals to amend the Constitution to prohibit retroactive tax rate increases).

172. See Shepsle, supra note 2, at 256 (arguing that a "division of labor committee system ... enables credible public commitments because it disables discretion of momentary majorities"); id. at 254-57.

173. Again, this may already be the practice of congressional committees most of the time. If so, the practice should be clearly articulated and publicized. One example of this practice occurred during recent hearings of the Ways and Means Committee when Committee Chairman Bill Archer stated publicly that no "loophole" would be reported out of committee unless accompanied by equivalent revenue offsets. See Archer Says No to "Rifleshots" at Hearings on Miscellaneous Proposals, 68 TAX Notes 239 (1995). One commentator has noted that congressional precommitment via the committee structure has become more difficult in recent decades because of procedural reforms that serve to "open" the tax-writing process to more interested parties than before. Stark, supra note 160. If that is so, this article sheds light on one significant cost of such a trend: the increased default-premium effect resulting from Congress's reduced ability to make credible precommitments in the tax area. 
of politics. ${ }^{174}$ It is the latter reason that I want to emphasize. The model of this sort of delegation is the allocation of control over the money supply to the Board of Governors of the Federal Reserve System. ${ }^{175}$ The Board is a semi-independent body, consisting of seven members appointed by the President with the advice and consent of the Senate for staggered fourteen-year terms. ${ }^{176}$ A member who has served a full term may not be reappointed.177 One of the principal justifications for allocating so much power to such an insular group is the perceived need to remove the control of the money supply from the influence of everyday politics.178 Specifically, if elected politicians, whether they be congresspersons or the President, were to maintain direct control over the money supply, they would inevitably be tempted to exercise that control in a manner that would maximize their chances of winning reelection but that undermined the long-run value to the economy of maintaining a stable money supply. ${ }^{179}$ To prevent this type of abuse, the authority is entrusted to a group of well-respected economic experts who are unlikely to be aligned with any particular politician and whose professional reputations depend largely upon their ability to maintain the long-run integrity of the money supply and the overall stability of the economy. ${ }^{180}$

As with the Federal Reserve Board, it is possible to understand the Treasury Department and the IRS as precommitment devices. Congress allocates a great deal of decisionmaking authority to the Treasury Department and in turn to the Service. Treasury is empowered by section 7805 of the Internal Revenue Code to issue regulations interpreting virtually any provision in the Code. ${ }^{181}$ This authority is quite broad, and, although the regulations promulgated under this statutory grant do not technically have the same binding

174. Another, perhaps more realistic way of describing the second reason for delegation is this: to allow Congress to avoid political accountability for hard decisions that must be made. I do not focus on that justification in this article.

175. See generally Alfred Broaddus, A Primer on the Fed (1988).

176. See id. at 14.

177. See id.

178. See id. ("The purpose of this [14-year] term of office is to insulate members from routine day-to-day political pressures.").

179. See, e.g, Kenneth Rogoff, Reputation, Coordination, and Monetary Policy, in MoDERN BUSINESS CYCLE THEORY 236 (Robert J. Barro ed., 1989) (demonstrating the benefits of credible government commitment to optimal monetary policy).

180. All of this is not to say that the Board of Govemors is entirely independent of Congress or the President. Together, Congress and the President could abolish the Fed, just as they created it, by statute. Moreover, there is a strong expectation that the Board will follow a monetary policy that is generally consistent with the current fiscal policy.

181. See I.R.C. § 7805 (1996). 
effect as the Code itself, as a practical matter, they have some binding effect for most taxpayers most of the time. In addition, sometimes when Congress enacts a new tax provision, it will insert a specific grant of regulatory authority, empowering the Treasury to issue regulations that are just as authoritative as the Code itself.

The Service also issues rulings of various types that provide a statement of how it will interpret specific Code provisions in certain circumstances. These rulings are sometimes issued publicly in the form of published revenue rulings. They are also sometimes issued directly to taxpayers as private-letter rulings, informing them how the Service would interpret a given Code provision in the taxpayers' specific circumstances. Both public and private rulings can be challenged by taxpayers as inconsistent with the Code; indeed, taxpayers challenge them quite often. Nevertheless, much more often taxpayers simply follow the rulings as if they were the law. Finally, the Treasury Department and the Service exercise lawmaking power in their decisions regarding enforcement practices, that is, the decisions concerning where to concentrate tax-enforcement resources, what arguments to make in litigation, how flexible to be in settlement negotiations with taxpayers, and on what issues to settle.

To explain this allocation of decisionmaking authority to the Treasury Department and to the Service, most commentators have relied primarily on the technical-expertise argument. Because the details of tax law are often extremely technical and arcane, it is considered necessary that a large measure of lawmaking authority be given to a group of well-trained and experienced experts in tax law and policy. That justification has merit. Nevertheless, another reason to allocate authority to these institutions is the benefit of policymaking stability over time. Unlike the members of the Federal Reserve Board, the high-level officials in the Treasury Department and in the IRS essentially serve at the discretion of the President; therefore, they are in some ways much more politically accountable for their decisions than members of the Fed are. The same technical nature of the tax field that serves to justify their grant of authority, however, also serves to protect them from political pressure. Most of the regulations and rulings interpreting the tax laws go unnoticed entirely by members of Congress. In addition, the people who are chosen to staff the high-level positions in the Treasury Department and in the Service, with the exception of the Secretary of Treasury, are almost always tax professionals, either tax lawyers or tax-law professors who have devoted their careers to understanding the tax laws and whose long-run professional success de- 
pends upon their reputations as tax experts and not their ability to carry out political agendas. 182

Perhaps Congress should, for precommitment reasons, increase the extent to which it delegates lawmaking authority to the Treasury Department and the Service, particularly in the area of incentive subsidies. Although a fully developed proposal along these lines is beyond the scope of this article, the basic outline of the idea should be obvious. The Treasury Department and the Service would be given a greater role in the design of such incentive subsidies as the incentive tax credits, as well as in decisions regarding whether to extend those credits and under what terms. In wielding this new power, the Treasury Department and the Service would be acting as an agent of Congress with the mandate to maximize the long-run efficiency of the economy, and they would continue to be subject to congressional oversight. They, however, would be one step removed from the heat of the political forces that sometimes cause the sort of government myopia of which Elster and others warn. ${ }^{183}$ Obviously, the tradeoff with such a proposal is that an enormous amount of power and control over the disbursement of a tremendous amount of government revenue would be placed in the hands of nonelected officials. Whether such a delegation would be unprecedented in magnitude or scope, however, is unclear.

\section{Built-In Precommitment Devices: Termination Dates and Up-Front Subsidies}

In addition to these general precommitment devices, there are various ways in which an incentive-subsidy provision could itself be designed so as to reduce the likelihood of its opportunistic repeal, repeal without transition relief. For starters, when enacting new incentive subsidies or when revising old ones, Congress could increase its use of termination dates. With certain types of incentive tax provisions, primarily those that are in the form of business credits, Congress commonly inserts a specific termination date. Then, if it decides to extend the provision in subsequent years, it does so either on a year-by-year basis or on some other periodic basis. For example, the research credit typically contains a specific termina-

182. That being said, one of the principal dangers of allocating authority to an agency is the risk of capture by the industry being regulated. See generally George J. Stigler, The Theory of Economic Regulation, 2 BeLI J. ECON. \& MGMT. ScI. 3 (1971). Arguably, however, the Treasury Department and the IRS are less susceptible to capture than a typical administrative agency, in part because of the relative size of their constituency.

183. ELSTER, supra note 1, at 87-103. 
tion date that is one year from the previous date of extension; ${ }^{184}$ thus, if the credit is to remain in effect, Congress must vote every year to extend it. In contrast, in 1990, Congress extended the termination date of the alcohol-fuel credit from December 31, 1992, to December 31, 2000.185 In some instances, credits that have been subject to specific termination dates are made "permanent," which simply means that, to repeal the provision in the future, instead of just allowing the provision to expire, Congress must pass a law to repeal it. 186

With an explicit termination date in effect, it becomes much more difficult for Congress to act opportunistically. Because the effective date of the termination is set in advance, the taxpayer can read for itself whether the provision will apply to a particular investment. Moreover, it is almost inconceivable that Congress would decide to apply the termination retroactively when the termination date arrives. ${ }^{187}$ That would be tantamount to the sort of extreme opportunism described in the government-contract example above, which Congress is likely to find unpalatable. ${ }^{188}$ Indeed, failure to leave the subsidy in effect at least until the stated termination date looks very much like a breach of our express contract. Therefore, an explicit termination date, in effect, serves as a guaranteed grandfathered effective date in the event the provision is not extended. How long the optimal termination period will be (one year or several years) is an empirical question that Congress would have to decide in each case. ${ }^{189}$

Next, Congress could increase its use of up-front incentive subsidies and reduce its use of installment subsidies. ${ }^{190}$ In the absence of

184. See I.R.C. § 41(h) (1996).

185. See Revenue Reconciliation Act of 1990, Pub. L. No. 101-508, 104 Stat. 1388-480 (codified in scattered sections of I.R.C.).

186. Before 1978, the investment tax credit had always been "temporary" in the sense that it always had included a termination date. In 1978, however, Congress made the ITC "permanent," which meant that the credit would remain in force until specific legislation was enacted to repeal or reduce it. See Revenue Act of 1978, Pub. L. No. 95-600, 92 Stat. 2763, 2824 (codified in scattered sections of I.R.C.).

187. Although it is fairly common for Congress to extend termination dates or even to make them "permanent," I have been unable to find a single example of Congress prematurely repealing a provision that had an explicit termination date.

188. Graetz recommends increased use of termination dates, but for a different purpose. He sees them as a means of putting taxpayers on notice that they should expect the tax laws to change and therefore should take that fact into account. See Graetz, supra note 9, at 87.

189. A one-year period may be insufficient in some circumstances. For example, the legislative history of the 1978 Act states that the reason the ITC was made permanent was that the uncertainty created by the "temporary" status was reducing the effectiveness of the ITC as an incentive device. See S. REP. No. 1263, 95th Cong., 2d Sess. 112 (1978).

190. For a definition of these terms, see supra Part I. 
a precommitment to provide guaranteed grandfathering, it can be argued that an up-front subsidy will give rise to a smaller default premium than an installment subsidy. If an installment subsidy is repealed, serious transition losses can occur even if the repeal is made nominally prospective, that is, in the absence of grandfathering. On the other hand, if an up-front subsidy is repealed, the use of a nominally prospective effective date would provide substantial, if not full, transition protection for those who had invested in reliance on the provision. Put differently, an up-front subsidy essentially comes with a built-in grandfather clause. Hence, to make the repeal of an up-front incentive subsidy nominally retroactive, Congress would essentially have to enact a special nominally retroactive tax designed to recapture the benefit previously conferred. Congress would be somewhat more reluctant to enact such a recapture tax than to enact a nominally prospective repeal of an installment subsidy. 191

Kaplow also observed that up-front subsidies contain built-in grandfather treatment. ${ }^{192}$ In keeping with his general position against transition relief, however, Kaplow concludes that the upfront design of incentive subsidies should be avoided.193 Goldberg also recognizes the difference between up-front subsidies and installment subsidies or, to use his terms, "one-time" and "periodic" subsidies. Unlike Kaplow, however, Goldberg extols the built-in grandfather feature of up-front subsidies. ${ }^{194} \mathrm{He}$ goes on, however, to suggest that periodic subsidies will always be inefficient.195 In my view, that claim goes too far. Although installment subsidies present a potential default-premium problem, it still is conceivable that the installment design, on balance, could be more efficient than the up-front design, just as a contract that is structured so that pay-

191. Golberg asserts that once an up-front subsidy has been enacted it cannot be repealed retroactively. See Goldberg, supra note 12, at 310. He also argues that "a one-time [upfront] subsidy is completely predictable because there is $100 \%$ certainty that it will be obtained." Id. at 327. Whereas, he contends that an installment subsidy "can never attain that level of predictability so long as there is a risk of uncompensated termination." Id. Although, as explained in the text that follows, I agree generally that up-front subsidies produce smaller default premiums than installment subsidies do, I think Goldberg overstates the case a bit.

192. See Kaplow, supra note 10 , at 587.

193. See id. ("Thus, the analysis of grandfather provisions should be applied to initial program design decisions concerning the appropriate timing of taxes and subsidies. Programs typically should not be designed so as to incorporate grandfathering, because it is generally undesirable." (footnote omitted)).

194. See Goldberg, supra note 12.

195. See id. at 306 ("Periodic subsidies are inefficient and are likely to decrease the horizontal equity of the tax system."). 
ments are made in installments could be more efficient (that is, produce more overall wealth for the contracting parties) than a contract that is structured so that a single lump-sum payment is made up front. For example, budgetary constraints in a particular year could make it impossible for Congress to enact an up-front incentive subsidy that is sufficiently large to induce the desired change in behavior; whereas, an installment subsidy, which spreads the payments over a larger number of budgetary periods, could be made more generous and therefore more effective. 196 Moreover, the default-premium effect of the installment design could theoretically be addressed by a credible government precommitment to providing grandfather treatment in the event the installment subsidy is repealed.197 In fact, it is theoretically possible that the most efficient means of reducing the default premium is not the up-front subsidy but some other form of grandfathering.

Thus, enacting incentive subsidies with specific termination dates or with up-front benefits are ways of decreasing the likelihood of retroactive repeal, that is, repeal without transition relief. Put differently, when Congress uses those devices, it not only promises taxpayers that it will subsidize their investments with an incentivetax provision but also signals with a fair degree of credibility that it will not renege on the deal.

\section{CONCLUSION}

As the tax-reform movement gathers momentum, there will be a temptation to use transition losses rather than tax-rate increases to meet revenue goals. This article has provided an argument for why Congress should resist that temptation, at least when the deduction, exclusion, or credit being repealed is an incentive subsidy. And it has provided an argument for why, in such situations, full transition relief in the form of grandfathered effective dates will often be appropriate. Moreover, this article has argued that whenever Congress decides to use an incentive subsidy as a means of altering taxpayers' incentives, it should give serious consideration to the optimal design of that subsidy. Among the considerations that should

196. Goldberg suggests that the only purpose served by spreading the cost of a subsidy over several budgetary periods is obfuscation, that is, to hide the true cost of the subsidy. See id. at 312. Indeed, obfuscation may play a role in the use of installment subsidies. However, there are economic as well as political reasons to use the installment form. For example, the use of the installment subsidy rather than an up-front subsidy of equal expected value may permit the government to avoid having to fund the subsidy with deficit financing.

197. Goldberg seems to disagree with this argument, even as a theoretical matter. See id. at 327 ("[T]he need for risk premiums for periodic subsidies cannot be avoided."). 
be taken into account are (a) whether the benefits of the subsidy should be paid up front or provided in installments over time, (b) whether express termination dates should be used, and (c) if the promise of a grandfathered effective date is to be included, whether grandfather treatment will be made transferable or not. In addition, if Congress finds itself unable keep its implicit or explicit promises not to repeal incentive-subsidy provisions without providing grandfather treatment, some sort of external precommitment technique should be considered, whether it be a formal contract, a legislative procedural reform, or a delegation of lawmaking authority to the Treasury Department.

The message of this article, however, is not limited to changes in the federal income tax laws. The important similarities between government contracts and incentive subsidies and the important differences between those two types of government action and other types of government action whose effects are less narrowly focused apply in nontax settings as well. Some of those nontax settings I have mentioned already, 198 but the point bears repeating: Whenever the government makes a policy decision (a change in the law or a change in the application of the law or whatever) the relevant government decisionmaker should consider the extent to which the new decision undermines earlier government commitments and therefore hinders the ability to make future commitments. When the default-premium effect is potentially large, the decisionmaker should consider implementing some form of transition relief.

I will conclude with an example of potential government opportunism that looms on the horizon as of this writing. The recent budget battles between the Republican-controlled Congress and the Democratic White House and the inability of the parties to reach a final agreement on a budget have increased the risk that the federal government will actually default on its debt obligations. In fact, Moody's Investor's Service publicly announced that, because of the budget deadlock, it was reviewing nearly $\$ 400$ billion of U.S. Treasury securities for possible downgrade. ${ }^{199}$ According to one Wall Street Journal report, "[i]f the rating agency downgrades U.S. debt, which would be an unprecedented action, it would almost certainly raise the cost of public borrowing." 200

198. See supra text accompanying notes 67-69.

199. See Fred Vogelstein, Moody's Puts Treasury Debt Up for Review, Wall St. J., Jan. 25,1996 , at C1.

200. Christopher Georges \& David Rogers, A Compromise is Developing on the Budget, WALl St. J., Jan. 25, 1996, at A24. 
If a budget deadlock and the threat of default can produce a downgrade in the U.S. credit rating, imagine what the effect of an actual default would be. A default of that sort would amount to a catastrophic form of government opportunism. Notwithstanding the recent announcement by Moody's, few experts believe that the government will in fact default on its obligations, precisely because of the size of the harm that would result.201 In this article I have emphasized that a similar sort of risk, the default-premium effect, lurks behind many government decisions, and although the magnitude of the effect in each case probably is minuscule compared to the prospect of a default on the federal debt, in the aggregate, over time, the costs may be quite high. Moreover, these may be costs that, with some careful attention to the design of an optimal transition policy, can be substantially reduced. The worst response to those costs, however, is to ignore them. 